\title{
EFEITO DE DIFERENTES SISTEMAS DE IRRIGAÇÃO SOBRE A DISSEMINAÇÃO DE Xanthomonas campestris pv. vesicatoria EM MUDAS DE TOMATE
}

\author{
ADRIANA TERAMOTO \\ Engenheiro Agrônomo
}

Orientador: Prof. Dr. KEIGO MINAMI

Dissertação apresentada à Escola Superior de Agricultura "Luiz de Queiroz", Universidade de São Paulo, para obtenção do titulo de Mestre em Agronomia, Área de Concentração: Fitotecnia.

\author{
PIRACICABA \\ Estado de São Paulo - Brasil
}

Fevereiro - 2003 


\section{Dados Internacionais de Catalogação na Publicação (CIP) DIVISÃO DE BIBLIOTECA E DOCUMENTAÇĀO - ESALQ/USP}

Teramoto, Adriana

Efeito de diferentes sistemas de irrigação sobre a disseminação de Xanthomonas campestris $p v$. vesicatoria em mudas de tomate / Adriana Teramoto. - - Piracicaba, 2003.

$48 \mathrm{p}$.

Dissertação (mestrado) - - Escola Superior de Agricultura Luiz de Queiroz, 2003.

Bibliografia.

1. Irrigação por microaspersão 2. Mancha-bacteriana 3. Mudas 4. Nebulização I. Título

CDD 635.652

"Permitida a copia total ou parcial deste documento, desde que citada a fonte - 0 autor" 
Aos meus grandes companheiros, Kenji e Felipe.

DEDICO

Aos meus queridos pais, Hisashi e Tomoko.

OFEREÇO 


\section{AGRADECIMENTOS}

À Escola Superior de Agricultura "Luiz de Queiroz" e ao Departamento de Produção Vegetal, pela oportunidade de realização deste curso.

Ao Conselho Nacional de Desenvolvimento Científico e Tecnológico (CNPq) pela bolsa concedida.

Ao professor Keigo Minami, pela orientação, amizade, sugestões e principalmente, por acreditar em mim, no meu potencial e capacidade de desenvolver este trabalho de pesquisa.

Ao professor Hiroshi Kimati, pela amizade, sugestões e dedicação demonstradas durante a elaboração, execução e conclusão deste trabalho.

À colega Alice, pelas bactérias, amizade e sugestões durante 0 desenvolvimento deste trabalho.

Ao professor Antonio Carlos Maringoni, que mesmo por e-mail enviou valiosas sugestões e dicas para o melhor desenvolvimento desta pesquisa.

Ao Dr. Carlos Alberto Lopes, pelas sementes de tomate, sem as quais este trabalho não seria possivel.

Aos professores dos Departamentos de Produção Vegetal e de Fitopatologia, pelos preciosos ensinamentos.

Aos amigos e funcionários do Departamento de Produção Vegetal, tanto do setor Horta quanto do setor Agricultura, chefiados pelo Erreinaldo e Edson, que sem a preciosa ajuda, não teria conseguido conduzir o experimento a contento.

Às amigas Gláucia, Karina, Aline e Cristiaini, pelo apoio e amizade. 
À Marise, responsável pela Clínica Fitopatológica, pela amizade e paciência por todas às vezes que recorri à ajuda dela na identificação das doenças que surgiram durante a fase do experimento.

Aos funcionários do Departamento de Fitopatologia, principalmente à Fernanda, Rodolfo e Heloísa, pela amizade, paciência, sugestões e pelo agradável convívio do dia-a-dia no laboratório.

À amiga Márcia, pelo carinho e amizade sincera.

Aos colegas de curso e amigos Fernando, Sally, Silvana, Valéria, Lea, Eliane, Maria Cecilia, Maria Carolina, Cristiane, Silvio, Sérgio, Nelson, Carlos, Hector e José Netto, pelo companheirismo e amizade.

Às secretárias da Pós-Graduação em Fitotecnia, Ivete e Luciane, pela preciosa ajuda com a parte burocrática do curso e pela amizade.

Às amigas Cláudia, Marina, Raquel e Renata, pela amizade e carinho e pelos nossos animados encontros.

À Erika e Elizabeth, amigas de longa data, pela amizade e pelos programas culturais.

Ao meu filho Felipe e ao meu grande companheiro Kenji, pela compreensão, carinho e apoio em todos os momentos.

Aos meus pais, Hisashi e Tomoko, e meu irmão, Rogério, pelo incentivo, carinho, amizade e, principalmente, por sempre poder contar com vocês.

A todos que, embora não mencionados, contribuíram para a realização deste trabalho. 


\section{SUMÁRIO}

Página

LISTA DE FIGURAS .................................................................. viii

LISTA DE TABELAS .................................................................. ix

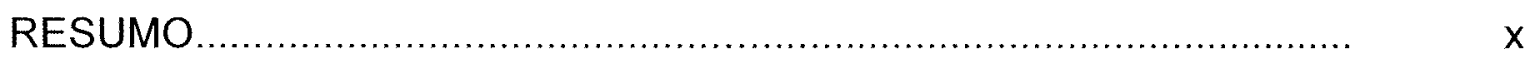

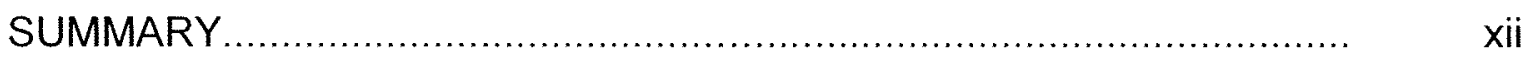

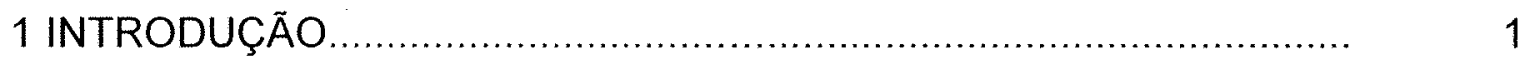

2 REVISÄO DE LITERATURA .................................................... 3

2.1 Importância econômica da cultura do tomate.................................. 3

2.2 Produção de mudas de tomate..................................................... 4

2.3 Xanthomonas campestris pv. vesicatoria.................................... 8

2.4 Ação do ambiente sobre Xanthomonas campestris pv. vesicatoria... 9

2.4.1 Umidade............................................................................ 10

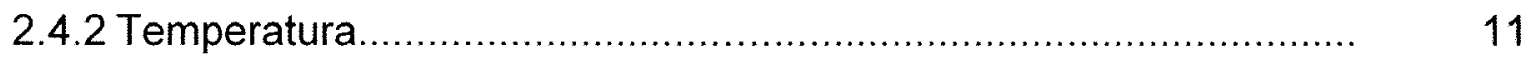

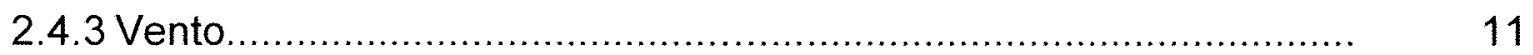

2.5 Ação da nutrição sobre o hospedeiro............................................. 11

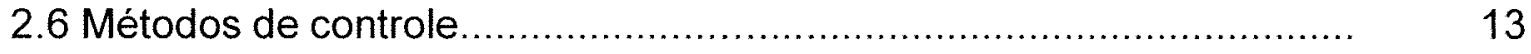

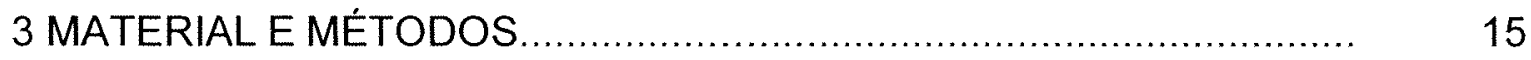

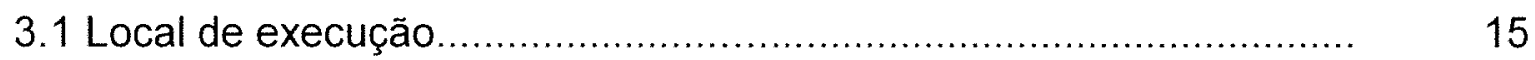




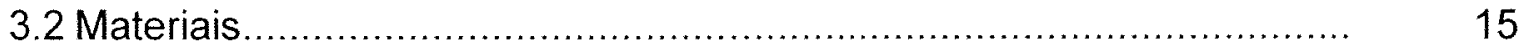

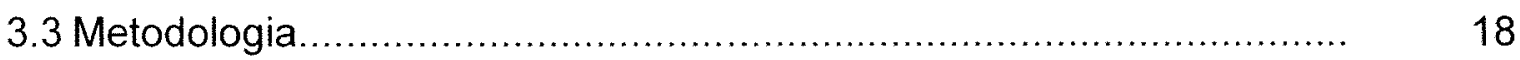

3.3.1 Obtenção, multiplicação, quantificação e preservação do isolado... 18

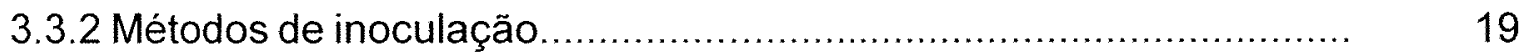

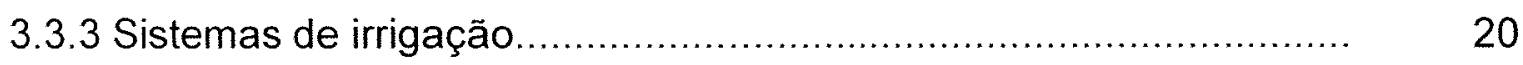

3.3.4 Avaliação da disseminação do patógeno.................................... 22

3.3.4.1 Tratamentos com sementes inoculadas................................ 22

3.3.4.2 Tratamentos com mudas inoculadas..................................... 24

3.3.4.3 Tratamentos com defensivos............................................. 24

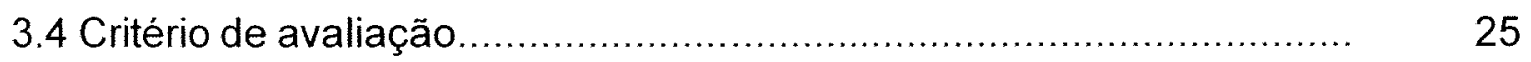

4 RESULTADOS E DISCUSSÃO .............................................. 28

4.1 Tratamento com sementes inoculadas................................... 28

4.2 Tratamento com mudas inoculadas........................................ 33

4.3 Tratamento com defensivos................................................ 37

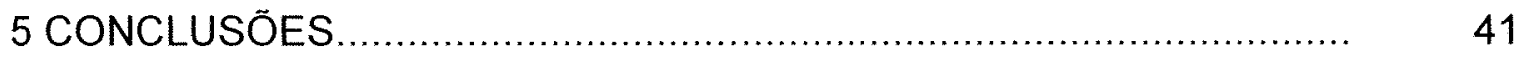

REFERÊNCIAS BIBLIOGRÁFICAS......................................... 42 


\section{LISTA DE FIGURAS}

Página

1 Sistema de produção de mudas 'floating', instalado dentro da estufa de produção de mudas

2 Crescimento de colônias de Xanthomonas campestris pv. vesicatoria (Xcv) no meio semi-seletivo Tween, após 7 dias a $28^{\circ} \mathrm{C}$ obtidas de amostras de folhas de tomate, submetidas à muda inoculada como fonte de inóculo primário. As colônias de Xcv são distinguidas das demais pela presença de halos esbranquiçados ao seu redor, em conseqüência da lipólise de Tween..

3 Sintomas típicos da mancha bacteriana em mudas inoculadas, para o teste de patogenicidade, 10 dias após a inoculação.

4 Resultados de incidência de bactérias com halo cristalizado no meio semi-seletivo Tween, na cultivar Ohio 8245 e no híbrido Hypeel 108, no sistema de irrigação por nebulização.

5 Resultados de incidência de bactérias com halo cristalizado no meio semi-seletivo Tween, na cultivar Ohio 8245 .

6 Resultados de incidência de bactérias com halo cristalizado no meio semi-seletivo Tween, no hibrido Hypeel 108.

7 Incidência de bactérias com halo cristalizado no meio semi-seletivo Tween.

8 Incidência de Xanthomonas campestris pv. vesicatoria no teste de patogenicidade. 


\section{LISTA DE TABELAS}

Página

1 Dados meteorológicos durante o periodo experimental, no município de Piracicaba - SP (Estação Agrometeorológica da ESALQ/USP - Departamento de Física e Meteorologia, Piracicaba - SP), 2002

2 Incidência de colônias bacterianas com halo cristalizado no tratamento com sementes inoculadas

3 Incidência de mancha bacteriana nas mudas inoculadas no tratamento com sementes inoculadas.

4 Incidência de colônias bacterianas com halo cristalizado no tratamento com mudas inoculadas.

5 Incidência de mancha bacteriana nas mudas inoculadas no tratamento com mudas inoculadas.

6 Incidência de colônias bacterianas com halo cristalizado no tratamento com sementes e mudas inoculadas.

7 Incidência de Xanthomonas campestris pv. vesicatoria no tratamento de defensivos 


\title{
EFEITO DE DIFERENTES SISTEMAS DE IRRIGAÇÃO SOBRE A DISSEMINAÇÃO DE Xanthomonas campestris pv. vesicatoria EM MUDAS DE TOMATE
}

\author{
Autora: ADRIANA TERAMOTO \\ Orientador: Prof. Dr. KEIGO MINAMI
}

\section{RESUMO}

Com o objetivo de avaliar a disseminação de Xanthomonas campestris pv. vesicatoria em mudas de tomate, produzidas no sistema de bandejas de isopor, utilizando-se sistemas de irrigação por nebulização, microaspersão e 'floating', realizou-se o presente trabalho no Setor Horta do Departamento de Produção Vegetal, da Escola Superior de Agricultura "Luiz de Queiroz". Para a produção de mudas, que ocorreu em ambiente protegido, foram utilizadas bandejas com 128 células preenchidas com um substrato comercial. O delineamento experimental foi inteiramente casualizado, com 3 repetições, no esquema fatorial de $3 \times 2$, sendo um dos fatores os sistemas de irrigação e o outro, as variedades de tomate. Cada parcela experimental (bandeja) recebeu conforme o tratamento, $2 \%$ de sementes inoculadas ou $1 \%$ de mudas inoculadas ou ainda $1 \%$ de sementes inoculadas e $1 \%$ de mudas 
inoculadas, como fonte de inóculo primário. Quando as mudas encontravam-se no ponto de transplantio para o campo ( 4 a 5 folhas definitivas e com 10 a $15 \mathrm{~cm}$ de altura), foram amostradas 10 mudas de cada parcela, com a finalidade de detectar a presença de Xanthomonas campestris pv. vesicatoria, nas folhas das mesmas. Para tanto, foi utilizado o meio semi-seletivo Tween, que quando em presença da bactéria estudada, formou um halo esbranquiçado ao redor da colônia. Após isolamento das colônias, foram realizados testes de patogenicidade em mudas de tomate com 20 dias após a semeadura. Se a suspensão contendo a bactéria isolada e inoculada era patogênica, depois de uns 10 a 15 dias surgiram sintomas típicos da mancha bacteriana nas folhas das mudas. Caso contrário, as mudas mantinham-se sadias. No tratamento com sementes inoculadas, não se verificou a presença da bactéria em nenhum dos sistemas de irrigação, assim como no tratamento com as mudas inoculadas. A açäo de 4 defensivos foi verificada também (oxitetraciclina associado com sulfato de estreptomicina; oxitetraciclina associado com cobre tribásico; oxitetraciclina e mancozeb associado com oxicloreto de cobre) no sistema de irrigação por nebulização, sendo que, tanto o oxitetraciclina associado com sulfato de estreptomicina, quanto o oxitetraciclina associado com cobre tribásico, mostraram-se sem incidência da bactéria, o oxitetraciclina com $7 \%$ e, o mancozeb associado com oxicloreto de cobre, com $27 \%$ de incidência de Xanthomonas campestris pv. vesicatoria. 


\section{EFFECT OF DIFFERENT IRRIGATION SYSTEMSONSPREAD OF Xanthomonas campestris pv. vesicatoria IN TOMATO SEEDLINGS}

Author: ADRIANA TERAMOTO Adviser: Prof. Dr. KEIGO MINAMI

\section{SUMMARY}

The spread of Xanthomonas campestris pv. vesicatoria was evaluated in tomato seedlings produced in trays, under fog, sprinkling and floating irrigation systems. This experiment was carried out at Plant Production Department of Escola Superior de Agricultura "Luiz de Queiroz" - Universidade de São Paulo - ESALQ-USP. Trays with 128 cells were used to produce seedlings in a greenhouse, with a commercial substrate. The experimental design was a completely randomized, with 3 replications, in a $3 \times 2$ factorial arrangement. One of these factors was the irrigation systems and the other, the tomato varieties. The experimental plot (tray) received $2 \%$ of inoculated seeds or $1 \%$ of inoculated seedlings or $1 \%$ of inoculated seeds and seedlings, as source of initial incidence of the Xanthomonas campestris pv. vesicatoria. Then, when seedlings were ready to be transplanted in the field (4-5 truth leaves and $10-15 \mathrm{~cm}$ of height), it was collected 10 seedlings of each parcel to detect the bacteria in the seedlings leaves. The semi-selective media was used to the 
detection of the bacteria. When the bacteria were present, zones of white crystals surrounded the yellow colonies. After isolating these colonies, was made pathogenic tests in tomato seedlings, which were 20 days after sowing. In the case of pathogenic bacteria, appeared typical symptoms of bacterial spot in the leaves of inoculated seedlings, 10 to 15 days after inoculation with the bacteria suspension. On the other hand, if the bacteria inoculated were not pathogenic, the seedlings grew healthy. There were no bacteria in any irrigation system, neither in the treatment of inoculated seeds nor in the inoculated seedlings. Four chemicals (oxitetracycline plus streptomycin sulphate; oxitetracycline plus tribasic copper; oxitetracycline and mancozeb plus copper oxychloride) was evaluated to control Xanthomonas campestris pv. vesicatoria, under fog irrigation system, in tomato seedlings with $1 \%$ of inoculated seeds and seedlings as initial incidence of the bacteria. Oxitetracycline plus streptomycin sulphate and oxitetracycline plus tribasic copper did not have any bacteria, oxitetracycline had $7 \%$ and mancozeb plus copper oxychloride had $27 \%$ of incidence of the bacteria. 


\section{INTRODUÇÃO}

A produção anual de tomates frescos no Mundo, chega a aproximadamente 100 milhões de toneladas. Como base comparativa, são cultivados 3 vezes mais batata e 6 vezes mais arroz ao redor do mundo (FAO, 2002). No entanto, mais de um quarto destes 100 milhões de toneladas são cultivados para o processamento industrial, o que faz o tomate ser a hortaliça mais processada mundialmente.

O Brasil se destaca em $6^{\circ}$ entre os maiores produtores de tomate industrial do mundo, só ficando atrás dos Estados Unidos, Itália, Espanha, Turquia e China (www.tomatonews.com, 2002). A produção brasileira é de 1,16 milhões de toneladas, sendo seu plantio concentrado em seis estados: Ceará, Pernambuco, Bahia, Goiás, Minas Gerais e São Paulo. Destacam-se no Estado de São Paulo, os municipios: Guaíra, Monte Alto, Taquaritinga, Novo Horizonte e Araçatuba (Silva \& Giordano, 2000).

Em todas as regiões produtoras há incidência de várias doenças fúngicas, bacterianas e viróticas. Destaca-se entre as doenças a mancha bacteriana, cujo agente causal é Xanthomonas campestris pv. vesicatoria, causando grande perda na produção, uma vez que atinge diretamente os frutos, depreciando-os para a comercialização.

Esta bactéria pode tanto ser transmitida por sementes infectadas como por plantas hospedeiras e restos de cultura. Ela também tem a característica de ser epífita, o que dificulta ainda mais seu controle, aliado ao fato de que não existem variedades resistentes e defensivos com controle efetivo para este patógeno. 
As condições ideais de desenvolvimento do patógeno são altas temperaturas e alta umidade relativa. É exatamente nestas condições que são produzidas as mudas de tomate. Estas mudas são aparentemente sadias, porém, podem estar infectadas com a mancha bacteriana, sendo a fonte de inóculo primário a própria semente e, os sintomas da doença só aparecem mais tarde, quando transplantadas no campo.

O sistema de produção de mudas, utilizado pela maioria dos produtores de mudas de hortaliças, é o de bandejas de poliestireno expandido em ambiente protegido, sendo o de 128 células recomendado para a produção de mudas de tomate (Barros, 1997; Souza \& Ferreira, 1997).

O sistema de irrigação utilizado por grandes produtores de mudas de tomate é o de nebulização. Como opções deste sistema tem-se a microaspersão e o "floating".

Portanto, este trabalho teve como objetivo verificar em qual sistema de irrigação, microaspersão, nebulização e "floating", houve disseminação da mancha bacteriana nas mudas de tomate industrial, sendo o inóculo inicial $2 \%$ das sementes inoculadas com a bactéria, ou $1 \%$ de mudas inoculadas em cada parcela experimental (bandeja). Foi testada também a eficiência de 4 defensivos, sendo 3 bactericidas e um cúprico associado com mancozeb, em uma única aplicação, durante a fase de produção de mudas no sistema de nebulização. 


\section{REVISÃO DE LITERATURA}

\subsection{Importância econômica da cultura do tomate}

O tomate é uma das hortaliças mais difundidas, importantes e estudadas em todo o mundo, pela sua palatabilidade, versatilidade na alimentação humana e seu valor nutritivo (Pinto \& Casali, 1980).

Os maiores produtores mundiais de tomate, em ordem decrescente, são: China, Estados Unidos, Índia, Turquia, Egito, Itália, Espanha e Brasil. O Brasil destaca-se com uma produção de 3.028.281t e ocupando uma área de 55.621ha (FAO, 2002).

Em termos de tomate para processamento industrial, esse destaque aumenta, pois o Brasil é o $6^{\circ}$, com uma produção de 1.600 .000 t, ficando atrás apenas dos Estados Unidos, Itália, Espanha, Turquia e China (www.tomatonews.com, 2002).

No Brasil, o plantio do tomate para processamento, encontra-se concentrado em seis estados: Ceará, Pernambuco, Bahia, Goiás, Minas Gerais e São Paulo. Nestes estados, estão instaladas 26 unidades processadoras, com capacidade para processar 17.080t diárias (Silva \& Giordano, 2000).

Devido a estes fatos, a cultura do tomate industrial tem elevada importância econômica e social, uma vez que exige um alto nível tecnológico e intensa utilização de mão-de-obra. Apesar do elevado indice de mecanização nas operações de preparo do solo, semeadura, adubação, irrigação e pulverização, são ainda necessários 120 homens/dia por hectare, na execução das tarefas de desbaste, capina e colheita manual. (Silva \& Giordano, 2000). 


\subsection{Produção de mudas de tomate}

$\mathrm{Na}$ cultura do tomate existem três processos básicos de produção de mudas: em sementeiras, em sementeira e em viveiro e em recipientes (Fontes, 1976; Filgueira, 1982; Sonnenberg, 1985), como por exemplo: os copinhos de jornal e as bandejas de isopor (Espinoza, 1991; Minami, 1995).

Atualmente, o processo de produção de mudas em bandejas de isopor vem sendo muito utilizado. Este sistema possui os seguintes componentes básicos: bandejas multicélulas, suporte de recipientes, substrato, proteção e controle ambiental, irrigação, nutrição, controle fitossanitário e administração (Minami \& Puchala, 2000).

Com relação às bandejas, estas são de polietileno expandido, leves e resistentes à umidade. As células são perfuradas, e isso permite que as raizes saiam, sofram um secamento natural e morram, sofrendo assim, uma poda natural das pontas das raizes, sem haver contato com o operador ou ferramenta, o que reduz a possibilidade de contaminação (Minami, 1995).

As bandejas devem ser colocadas sobre suportes para que fique a 30 $\mathrm{cm}$ do solo. O sistema mais comum e barato para a construção dos suportes consiste em esticar dois ou três fios paralelos de arame de aço galvanizado, para sustentar cada fileira de bandejas (Giordano et al., 2000).

No mercado existe grande diversidade no formato e tamanho das bandejas, a recomendada para produção de mudas de tomate é aquela de 128 células, com $6,20 \mathrm{~cm}$ de altura, $37,5 \mathrm{~cm}$ de largura e $67,5 \mathrm{~cm}$ de comprimento (Minami, 1995 e Souza \& Ferreira, 1997).

Apesar dessas recomendações, deve-se levar em consideração o aspecto econômico, o que leva os produtores de mudas a utilizar bandejas de 200 células para a produção de mudas de tomate (Giordano et al., 2000).

Um outro componente do sistema de produção de mudas em bandejas é o substrato. Minami \& Puchala (2000) definem como substrato um material ou uma mistura deles, de origem orgânica e/ou mineral e/ou sintética, que deve ser estável e ter suas composições química e física balanceadas, a 
fim de permitir o bom desenvolvimento das raizes das mudas e podendo, ainda, regular a disponibilidade de água e nutrientes para as plantas. Esse substrato pode ser adquirido comercialmente ou produzido na propriedade, desde que se teste a proporção dos ingredientes, antes de se iniciar a produção de mudas em grande escala (Giordano et al., 2000).

O próximo componente é a proteção, onde a produção de mudas é feita utilizando-se túneis plásticos, sombrite ou estufas. Essa proteção possibilita um controle contra rajadas de vento, sobretudo de areia, excesso de chuva, temperaturas muito altas ou muito baixas, invasão de pragas, principalmente as sugadoras, granizos, entre outros (Minami, 1995).

A estufa, estrutura bastante difundida entre os produtores de mudas hortícolas, deve ser coberta com plástico apropriado e fechada lateralmente com tela de malha estreita, para impedir a entrada de insetos, principalmente os afídeos (Giordano et al., 2000). Em locais com temperatura elevada e baixa umidade relativa é recomendável a colocação de tela do tipo sombrite, na parte interna da estufa, para reduzir a evapotranspiração (Minami, 1995; Giordano et al., 2000).

Um dos pontos-chave no sucesso da produção de mudas de alta qualidade é a irrigação, pois a necessidade de água é sentida em todas as fases de produção da muda. Qualquer restrição no suprimento de água reduz a taxa e a percentagem de germinação, a emergência das sementes e a taxa de desenvolvimento das mudas (Minami, 1995).

$\mathrm{Na}$ produção de mudas, a irrigação deve fornecer água de boa qualidade em quantidades iguais para todos os recipientes, uniformemente e com gotas pequenas, que permita manter um nivel adequado de água. 0 excesso de água causa lixiviação de nutrientes, crescimento de algas, musgos e doenças. A falta repentina de água provoca aumento da salinidade, contração do substrato, e, em casos severos, morte das mudas. Através da irrigação pode-se reduzir a temperatura ambiente, quando necessário (Minami, 1995). 
Os sistemas que podem ser utilizados na irrigação das bandejas são: aspersão, gotejamento, nebulizantes, pulverizadores em barra e por capilaridade.

Andriolo et al. (2001) verificaram o crescimento e o desenvolvimento de mudas de tomateiro e melão empregando os métodos de irrigação por microaspersão, inundação subsuperficial e flutuação e, constataram que, a inundação subsuperficial foi o método que mais favoreceu o desenvolvimento da parte aérea das mudas, tanto para o tomateiro como para o melão.

Em termos nutricionais, diversos autores têm estudado a nutrição de plantas horticolas, determinando a curva de crescimento e de extração de nutrientes dessas espécies (Haag et al., 1981; Haag \& Homa, 1981). A quantidade de nutrientes extraída pelas diversas espécies durante a fase de muda varia em função da espécie, da variedade ou do cultivar e do prazo necessário para a formação dessa muda. O desempenho da muda também depende de quantidades desses nutrientes, que devem ser fornecidos através de uma adubação adequada (Carmello, 1995).

Melton \& Dufault (1991) estudaram os efeitos de diversas doses de N, $\mathrm{P}$ e $\mathrm{K}$ no crescimento do tomate transplantado, e determinaram as doses mais adequadas para o melhor desenvolvimento deste $\left(225 \mathrm{mg} \cdot \mathrm{L}^{-1}\right.$ de N, $45 \mathrm{mg} \cdot \mathrm{L}^{-1}$ de $\mathrm{P}$ e $25 \mathrm{mg} . \mathrm{L}^{-1}$ de K). Já Liptay \& Nichols (1993), estudaram apenas os efeitos de diversas doses de $\mathrm{N}$ aplicados durante a produção de mudas de tomate, no crescimento radicular após transplante no campo. Os autores determinaram a dose que proporcionou a máxima sobrevivência, crescimento $e$ produção precoce no campo (100 a $200 \mathrm{mg} . \mathrm{L}^{-1}$ )

Ainda com relação à parte nutricional, Giordano et al. (2000) recomendam quando ocorrer deficiência de $\mathrm{N}$, fazer a aplicação de uréia a $5 \%$ ou fosfato monoamônico a $0,5 \%$ pela água de irrigação ou via foliar. Recomendam ainda, dependendo da composição do substrato utilizado, a aplicação de fertilizante foliar formulado com micro e macronutrientes, seguindo a recomendação do fabricante. 
Com relação ao controle fitossanitário, Espinoza (1991) comenta que a produção de mudas em bandejas exige cuidados especiais para evitar o aparecimento e disseminação de doenças e, especial atenção deve ser dispensada ao controle da temperatura e umidade.

Pereira \& Martinez (1999) acrescentam que a semente deve estar isenta de patógenos, que é uma característica fundamental à qualidade da semente. No entanto, existem apenas testes de sanidade de sementes para detecção de vários fungos, sendo que para bactérias patogênicas o teste se mostra inadequado (Nascimento \& Moraes, 1990).

Gitaitis et al. (1992) acrescentam ainda que, a circulação de ar e o tempo de irrigação são manejados para reduzir a duração de umidade na folha, sem chegar a causar estresse hídrico. As plantas devem ser manuseadas o mínimo possivel, a fim de evitar transmissão mecânica de bactérias e vírus. Para prevenir a transmissão do vírus do mosaico do fumo, os trabalhadores não devem ser fumantes.

O último item, administração, tem extrema importância, uma vez que o sistema de produção de mudas, para ser eficiente precisa de um mínimo de tecnificação, e como possui vários componentes, esses devem ser supervisionados e estarem sempre em perfeito estado de uso. Atualmente existem firmas produtoras das mais diversas espécies de mudas de hortaliças, sendo um negócio rentável quando bem administrado.

Hoje em dia, grandes produtores de tomate industrial adquirem ou produzem mudas nesse sistema, por apresentar a grande vantagem das mudas serem de alta qualidade, pois o sistema propicia: ótimo ambiente para a germinação de sementes, maior controle do crescimento das mudas, cada muda cresce independentemente uma da outra, as mudas podem ser condicionadas, o sistema exige o uso de técnicas modernas, o transplante é facilitado (Minami \& Puchala, 2000).

Ainda tem as vantagens de ter maior equilibrio entre parte aérea e o sistema radicular, economia de sementes, economia de defensivos, maior 
rendimento e aproveitamento de mão-de-obra, economia de irrigação, maior uniformidade da cultura, aumento de 20 a $30 \%$ no diferencial de produtividade (Souza \& Ferreira, 1997), facilita o transporte ao local definitivo, reduzir a necessidade de replantio (Silva \& Giordano, 2000), economia de substrato e de área de viveiro (Oliveira et al., 1993).

\subsection{Xanthomonas campestris pv. vesicatoria}

Causa a doença conhecida como mancha bacteriana. Foi descrita e estudada por Gardner \& Kendrick em 1921, em Indiana, nos Estados Unidos. Naquela época era ainda denominada Bacterium vesicatorium Doidge e de ocorrência nas culturas de batata, pimentão e todas as variedades de tomate.

No Brasil foi detectada pela primeira vez em Mairiporã, Piedade e Ribeirão Preto, em 1958 (Ciccarone \& Dowson, 1959; Kramer, 1959). Atualmente, é uma das doenças mais importantes na cultura do tomate, ocorrendo tanto em tomate para consumo in natura como em tomate para processamento industrial (Lobo, 2000).

É uma bactéria gram-negativa, na forma de bastonetes móveis de flagelo polar, podendo formar cápsulas. Em meio de extrato de carne as colônias são amarelas (Kurozawa \& Pavan, 1997) rodeadas por zonas de cristais brancos quando repicadas em meio Tween, devido à ação de enzimas lipolíticas da bactéria sob os sais de cálcio dos ácidos graxos (McGuire et al., 1986).

Epidemias são favorecidas por condições de alta umidade que favorecem a multiplicação, disseminação, penetração e colonização dos tecidos do hospedeiro (Timmer et al., 1987). Ventos fortes associados a chuvas pesadas também favorecem a disseminação da bactéria, dentro da cultura ou entre culturas próximas (Volcani, 1969).

A disseminação planta a planta ocorre também por respingos de água da chuva ou irrigação por aspersão (Rotem \& Cohen, 1966; Pohronezny et al., 1990; Latin et al., 1995), implementos agrícolas, pelos trabalhadores durante os 
tratos culturais e, à longa distância, por meio de sementes contaminadas (Gardner \& Kendrick, 1921).

A bactéria penetra na planta através dos estômatos (Gardner \& Kendrick, 1921), hidatódios e ferimentos (Vakili, 1967). Após a penetração, mesmo se a umidade do solo e do ar forem baixas, a bactéria pode multiplicar e provocar um leve amarelamento e/ou necrose internerval nos folíolos.

Poucas horas após uma chuva mais pesada podem-se constatar áreas com encharcamento na face inferior dos folíolos, que evoluem para manchas necróticas, que normalmente coalescem levando à queima das folhas e expondo os frutos à queima de sol ou escaldadura. Enquanto as manchas são individuais, podem ser confundidos com a pinta-bacteriana (Kurozawa \& Pavan, 1997; Silva \& Giordano, 2000).

Nos frutos, as lesões são maiores, mais claras e mais profundas que as da pinta-bacteriana. Também provoca queda das flores quando o ataque ocorre por ocasião do florescimento (Kurozawa \& Pavan, 1997; Silva \& Giordano, 2000).

O patógeno pode sobreviver em restos de cultura (Peterson, 1963; Jones et al., 1986) e em outras plantas hospedeiras (Goode \& Sasser, 1980; Jones et al., 1986; Gitaitis et al., 1992), tais como pimentas, pimentão, berinjela, batateira, tomateiro selvagem, Solanum nigrum, Datura spp. e Physalis spp. Nestas, a bactéria pode sobreviver como epifita (McGuire et al., 1991), raramente causando lesões em seus órgãos.

\subsection{Ação do ambiente sobre Xanthomonas campestris pv. vesicatoria}

\subsubsection{Umidade}

A água presente na atmosfera e no solo tem papel relevante sobre os diferentes agentes infecciosos que atacam tanto a parte aérea como o sistema radicular da planta. A água, na forma de chuva, orvalho ou irrigação, altera a 
umidade do ar e do solo, contribuindo ou prejudicando as atividades das bactérias (Bedendo, 1995).

A umidade relativa do ar exerce uma grande influência no favorecimento do desenvolvimento da mancha bacteriana, principalmente em regiōes de alta umidade relativa onde ocorre a formação de orvalho e as folhas se mantêm úmidas por longo período do dia, principalmente aquelas localizadas na parte inferior das plantas (Silva \& Giordano, 2000). Para exemplificar este fato, Pohronezny et al. (1990) verificaram que a incidência da mancha bacteriana foi menor, quando mudas de tomate produzidas através de semeadura direta, foram desbastadas à tarde (44\%), quando a folhagem estava seca ao invés das plantas desbastadas pela manhã, quando a folhagem ainda estava úmida de orvalho $(87 \%)$.

Foi comprovada que a irrigação por aspersão causa uma maior severidade da mancha bacteriana, do que irrigação por sulco (Rotem \& Cohen, 1966). Isto ocorreu pelo fato de que a irrigação por sulco não afetou o microclima predominante no campo, sendo que a irrigação por aspersão foi associada ao aumento da umidade relativa e redução da temperatura do ar.

Também foi comprovado que o aumento da disseminação do patógeno e uma maior incidência ocorreu no sistema de aspersão e não no sistema de sulco, e a disseminação da doença estava relacionada com a direção dos ventos predominantes da região (Volcani, 1969).

Latin et al. (1995) concluíram, para a cultura de melancia, que irrigação por aspersão resultou em maiores niveis de disseminação de Acidovorax avenae subsp. citrulli em mudas quando comparado ao método de irrigação por infiltração, e que reduzidas umidades relativas após a irrigação resultaram em menores niveis da doença, para ambos os tipos de irrigação utilizados.

\subsubsection{Temperatura}

A maioria dos patógenos, particularmente aqueles presentes em região tropicais e subtropicais, é capaz de crescer numa ampla faixa de temperatura 
(Bedendo, 1995), porém, a doença desenvolve-se mais rapidamente à temperatura contínua de $24^{\circ} \mathrm{C}$, que é a temperatura favorável ao bom crescimento vegetativo da planta hospedeira. A próxima temperatura mais favorável foi de $24^{\circ}$ e $28^{\circ} \mathrm{C}$ à noite, independendo da temperatura diurna.

Num caso extremo, a temperatura noturna de $16^{\circ} \mathrm{C}$ suprimiu a doença, independendo da temperatura diurna (Nayudu \& Walker, 1960). Já Morton (1966) verificou que $25^{\circ} \mathrm{C}$ a $27,5^{\circ} \mathrm{C}$ foram temperaturas ótimas para o máximo desenvolvimento de sintomas da doença nas folhas de tomate, em tubo de ensaio com temperatura constante. Nakamura (1990) demonstrou que a temperatura mais favorável foi um pouco acima da faixa considerada ótima pelos autores citados acima, que foi de $29,0-30^{\circ} \mathrm{C}$.

\subsubsection{Vento}

O vento associado à irrigação por aspersão foi comprovadamente ser um dos principais agentes de disseminação da bactéria, como provou Volcani (1969) em seu estudo relacionando sistemas de irrigação (aspersão e sulco) e disseminação da doença, com a direção dos ventos predominantes da região.

A ação concomitante de chuvas e ventos é extremamente eficiente na disseminação de bactérias fitopatogênicas, a curta distância, de uma planta infectada para suas vizinhas, inclusive redistribuindo o inóculo na cultura. Gotas de chuva, incidindo nas lesões, dissolvem o aglomerado de bactérias ao mesmo tempo em que o impacto da gota fragmenta-a em gotículas bem menores. Essas goticulas, contendo células da fitobactéria, ficam em suspensão no ar. O vento se encarrega de direcionar essas gotículas para órgãos da mesma planta ou para as plantas vizinhas (Romeiro, 2000).

\subsection{Ação da nutrição sobre o hospedeiro}

A nutrição mineral também pode se constituir num fator de predisposição de plantas ao ataque de patógenos. Quando os elementos minerais requeridos pelo vegetal são fornecidos de forma adequada, a planta 
apresenta maior capacidade de reação à doença. No entanto, o excesso ou a escassez destes elementos pode tornar as plantas predispostas à ação de agentes causais de doenças (Bedendo, 1995).

O N tem importante papel na ocorrência de doenças, não só em função de uma aplicação desequilibrada, mas também pela forma utilizada. $\mathrm{O}$ uso do $\mathrm{N}$ em excesso pode favorecer o patógeno, por aumentar a suculência dos tecidos, retardar a maturação dos mesmos e prolongar a duração do período vegetativo. Assim como a deficiência de $\mathrm{N}$ provoca subdesenvolvimento da planta, tornando-a menos vigorosa e, portanto, mais predisposta a doenças (Bedendo, 1995).

O K, de uma maneira geral, exerce efeito desfavorável a doenças. Provavelmente, tem uma atuação direta, dificultando o estabelecimento e desenvolvimento do patógeno no hospedeiro, além de atuar indiretamente, promovendo a cicatrização de ferimentos e dificultando a penetração de agentes patogênicos (Bedendo, 1995).

Nayudu \& Walker (1960) estudando a mancha bacteriana do tomateiro, influenciada por temperatura e pela idade e nutrição do hospedeiro, concluíram que em tomateiros supridas com uma solução nutritiva com valores altos de potencial osmótico, porém balanceada, o crescimento da planta era limitado e o desenvolvimento da doença era visivelmente inibido, paralelamente aos efeitos de altas concentrações de qualquer um dos nutrientes: N, P ou K.

Jones et al. (1988) verificaram as influências das taxas de fertilização de $\mathrm{K}$ e $\mathrm{N}$, na suscetibilidade de plantas de tomate irrigadas por gotejamento à mancha bacteriana. Concluíram que, aumentando os valores de $\mathrm{N}$ houve redução na severidade da doença, mas o efeito do aumento do $K$ foi inconsistente.

McGuire et al. (1991) monitoraram populações epifíticas de Xanthomonas campestris pv. vesicatoria para verificar a influência da adubação nitrogenada e potássica, em plantas de tomate. $O$ resultado obtido foi que menores populações epifíticas do patógeno desenvolveram nas plantas, que 
receberam os valores mais altos de $\mathrm{N}$ e $\mathrm{K}$. Desfolha foi mais severa com valores menores de $\mathrm{N}$, mas os valores de $\mathrm{K}$ aplicado tiveram pouca influência.

\subsection{Métodos de controle}

Recomenda-se plantar mudas selecionadas, produzidas a partir de sementes de boa qualidade. Quando suspeitas de contaminação, tratar as sementes com calor de $50^{\circ} \mathrm{C}$ por 20 minutos (Lopes \& Quezado-Soares, 1997). Ou imersão em água quente a $56^{\circ} \mathrm{C}$ durante 30 minutos, ou em $5 \% \mathrm{HCl}$ durante 5 horas ou em $5 \%$ hipoclorito de sódio por 20 minutos (Kurozawa \& Pavan, 1997). Evitar o cultivo próximo a lavouras mais velhas de tomate ou de pimentão. Não plantar tomate seguidamente na mesma área obedecendo-se rotação de culturas por um período mínimo de 3 anos (Kurozawa \& Pavan, 1997; Lopes \& Quezado-Soares, 1997) ou intercalados com pimentão (Lopes \& Quezado-Soares, 1997).

Para o controle químico, Maringoni et al. (1986) testaram diversos fungicidas e antibióticos para o controle da mancha bacteriana e de maneira geral, não apresentaram resultados satisfatórios. Os fungicidas cúpricos também não reduziram a área foliar afetada pela bactéria e nem aumentaram significativamente a produtividade. No entanto, o tratamento com oxicloreto de cobre, no segundo ensaio, apresentou menor número de frutos doentes, diferindo da testemunha.

Mclnnes et al. (1988) não obtiveram controle do patógeno utilizando fungicida cúprico associado a mancozeb. Gitaitis et al. (1992) em concordância com os resultados obtidos por Maringoni et al. (1986) afirmaram que o controle químico é difícil, pois estreptomicina e bactericidas cúpricos foram usados durante muitos anos para reduzir a incidência da mancha bacteriana e isso acarretou resistência do patógeno a esses produtos. Contraditoriamente, Lopes \& Quezado-Soares (1997) recomendaram aplicar fungicidas cúpricos ou antibióticos agrícolas como Agrimicina e Mycoshield. 
Outra medida de controle recomendada é não irrigar excessivamente. Está comprovada que a irrigação por aspersão causa uma maior severidade da mancha bacteriana do que irrigação por sulco (Rotem \& Cohen, 1966). Isto ocorreu pelo fato que a irrigação por aspersão foi associado ao aumento da umidade relativa e redução da temperatura do ar.

Como mais uma recomendação de medida de controle seria eliminar os restos culturais logo após a colheita, uma vez que a bactéria é capaz de sobreviver nos restos culturais (Peterson, 1963; McCarter et al., 1983; Lopes \& Quezado-Soares, 1997).

Finalmente, como última medida de controle, Kurozawa \& Pavan (1997) recomendam cultivares e híbridos que tenham alta capacidade de brotação e recomposição da parte aérea, para plantios em épocas chuvosas, como exemplo tem-se a cultivar Ohio 8245 (Giordano et al., 2000). 


\section{MATERIAL E MÉTODOS}

\subsection{Local de execução}

O preparo de inóculo do isolado patogênico de Xanthomonas campestris pv. vesicatoria e sua quantificação foram realizados no laboratório do Departamento de Entomologia, Fitopatologia e Zoologia Agrícola, da Escola Superior de Agricultura "Luiz de Queiroz" (ESALQ), em Piracicaba, SP. Toda a parte fitopatológica do experimento teve o acompanhamento do Prof. Dr. Hiroshi Kimati e da Pós-graduanda pesquisadora da Embrapa Hortaliças Alice Maria Quezado-Soares.

O experimento foi conduzido no Departamento de Produção Vegetal, Setor de Horticultura e Agricultura, da ESALQ, no período de junho a novembro de 2002. Os dados meteorológicos estão descritos na Tabela 1.

\subsection{Materiais}

Para determinar a ação dos diferentes sistemas de irrigação na disseminação de Xanthomonas campestris pv. vesicatoria foram utilizados materiais considerados como resistente e suscetivel ao patógeno. No caso da avaliação da ação dos defensivos só foi considerado o material suscetível.

Foram utilizados os seguintes materiais:

a) cultivar tolerante Ohio 8245

- Banco de Sementes da Embrapa Hortaliças

- Cultivar de polinização aberta

- Origem: Universidade de Ohio

- Ciclo: 120 a 125 dias (da semeadura à colheita) 
- Índice de concentração de maturação de frutos: médio para baixo

- Resistência a Verticillium raça 1 e a Fusarium raça 1 e 2

b) híbrido Hypeel 108

- Empresa de Sementes Petoseed

- Ciclo de 120 a 125 dias

- Índice de concentração de maturação dos frutos: bom

- Resistência a Verticillium raça 1 , Fusarium raça 1 e 2 , nematóides de galhas e a pinta-bacteriana (Pseudomonas syringae pv. tomato)

Foram utilizados também os seguintes defensivos:

a) oxitetraciclina + sulfato de estreptomicina

- Nome comercial: Agrimicina

- Laboratórios Pfizer Ltda

- Composição: $15 \mathrm{~g} \cdot \mathrm{kg}^{-1}$ de oxitetraciclina e $150 \mathrm{~g} \cdot \mathrm{kg}^{-1}$ de estreptomicina

- Classe: bactericida e fungicida

- Grupo químico: dos antibióticos

- Tipo de formulação: pó molhável

- Classe toxicológica I

- Intervalo de aplicações: 15 dias

- Período de carência: 14 dias

b) oxitetraciclina + cobre tribásico

- Nome comercial: Agrimaicin

- Laboratórios Pfizer Ltda.

- Composição: $30 \mathrm{~g} \cdot \mathrm{kg}^{-1}$ de oxitetraciclina e $400 \mathrm{~g} \cdot \mathrm{kg}^{-1}$ de cobre metálico

- Classe: bactericida e fungicida

- Grupo químico: dos antibióticos e cúpricos

- Tipo de formulação: pó molhável 
- Classe toxicológica III

- Intervalo de aplicações: 7 a 15 dias

- Período de carência: 7 dias

c) oxitetraciclina

- Nome comercial: Mycoshield

- Laboratório Pfizer Ltda.

- Composição: $780 \mathrm{~g} \cdot \mathrm{kg}^{-1}$ de oxitetraciclina

- Classe: bactericida e fungicida

- Grupo químico: dos antibióticos

- Tipo de formulação: pó molhável

- Classe toxicológica II

- Intervalo de aplicação: 20 dias

- Período de carência: 7 dias

d) mancozeb+oxicloreto de cobre

- Nome comercial: Dithane PM e Reconil

- Rohm and Haas Brasil Ltda. e Sandoz S.A.

- Composição: $800 \mathrm{~g} \cdot \mathrm{kg}^{-1}$ de mancozeb e $350 \mathrm{~g} \cdot \mathrm{kg}^{-1}$ de cobre metálico

- Classe: fungicida e fungicida à base de cobre

- Grupo químico: ditiocarbamato e cobre

- Tipo de formulação: pó molhável e pó molhável

- Classe toxicológica III e IV

- Intervalo de aplicação: 5 a 7 dias e 7 a 15 dias

- Período de carência: 7 dias e 1 dia. 
Tabela 1. Dados meteorológicos durante o período experimental, no município de Piracicaba - SP (Estação Agrometeorológica da ESALQ/USP - Departamento de Física e Meteorologia, Piracicaba $-\mathrm{SP}), 2002$.

\begin{tabular}{lcccc} 
Mês & $\begin{array}{c}\text { Temp.max. } \\
\left({ }^{\circ} \mathrm{C}\right)\end{array}$ & $\begin{array}{c}\text { Temp.min. } \\
\left({ }^{\circ} \mathrm{C}\right)\end{array}$ & $\begin{array}{c}\text { Temp.média } \\
\left({ }^{\circ} \mathrm{C}\right)\end{array}$ & $\begin{array}{c}\mathrm{UR}^{4} \\
(\%)\end{array}$ \\
\hline \multirow{2}{*}{ Junho } & 27,9 & 12,6 & 20,3 & 68,07 \\
Julho & 25,2 & 10,2 & 17,7 & 67,99 \\
Agosto & 27,3 & 11,0 & 19,2 & 62,23 \\
Setembro & 27,5 & 13,6 & 20,6 & 60,53 \\
Outubro & 33,8 & 18,8 & 26,3 & 54,23 \\
Novembro & 30,6 & 18,8 & 24,7 & 81,10
\end{tabular}

${ }^{1}$ Temp.max.:Temperatura máxima; ${ }^{2}$ Temp.min.:Temperatura mínima; ${ }^{3}$ Temp.média:Temperatura média e ${ }^{4}$ UR:Umidade Relativa.

\subsection{Metodologia}

\subsubsection{Obtenção, multiplicação, quantificação e preservação do isolado}

$\mathrm{O}$ isolado de Xanthomonas campestris pv. vesicatoria foi cedido pela pesquisadora da Embrapa Hortaliças Alice Maria Quezado-Soares, e tinha como identificação o seguinte código: CNPH - XA 215.

Para o preparo do inóculo, tanto para o teste de patogenicidade quanto para inoculação das sementes, o patógeno foi repicado para placas de Petri contendo nutriente agar (NA), cujos ingredientes foram os seguintes para $1 \mathrm{~L}$ de meio: $3 \mathrm{~g}$ de extrato de carne; $5 \mathrm{~g}$ de peptona; $5 \mathrm{~g}$ de extrato de levedura; $10 \mathrm{~g}$ de 
dextrose e $20 \mathrm{~g}$ de agar. Após periodo de 48 horas de incubação em estufa à temperatura de $28^{\circ} \mathrm{C}$, foi adicionada água estéril (água destilada e autoclavada à $120^{\circ} \mathrm{C}$ e pressão de $1 \mathrm{~atm}$ ) à placa e raspada com o auxilio da alça de Drigalski para o preparo da suspensão. Posteriormente, uma amostra desta suspensão foi quantificada em espectrofotômetro Hitachi U-200, do Laboratório de Parasitismo de Plantas. O comprimento de luz utilizado foi de $600 \mathrm{~nm}$ e medido 0,3 de Absorbância, o que totalizou aproximadamente $10^{8}$ ufc. $\mathrm{mL}^{-1}$ do patógeno em estudo.

Para a preservação do isolado da bactéria, foi utilizada a solução de tampão fosfato, cujos ingredientes para o preparo de $200 \mathrm{~mL}$ da solução foram os seguintes: $0,3 \mathrm{~g}$ de potássio fosfato dibásico e $0,2 \mathrm{~g}$ de potássio fosfato monobásico, devidamente autoclavada.

\subsubsection{Métodos de inoculação}

Foram inoculadas mudas com 60 dias após a semeadura, contidas em 2 bandejas de 128 células, sendo uma da cultivar tolerante Ohio 8245 e outra do híbrido Hypeel 108, com suspensão bacteriana de Xanthomonas campestris pv. vesicatoria, na concentração de $10^{8}$ ufc $\mathrm{mL}^{-1}$, com auxílio de um pulverizador manual com capacidade de $500 \mathrm{~mL}$. As folhas foram pulverizadas nas superficies abaxial e adaxial, até o ponto de escorrimento das gotas.

Apesar das mudas serem 'velhas', estas estavam com porte pequeno $( \pm 10 \mathrm{~cm}$ de altura e com 4 a 5 folhas definitivas) devido ao intenso frio que fez durante o período de crescimento das mudas (temperaturas médias dos meses de julho e agosto: $17,7^{\circ} \mathrm{C}$ e $19,2^{\circ} \mathrm{C}$, respectivamente, sendo a temperatura ideal de crescimento das mudas em torno de $24^{\circ} \mathrm{C}$ ).

Após a inoculação as mudas ficaram um período de 24 horas em câmara úmida (envoltas em sacos plásticos transparentes e colocadas embaixo das bancadas). Depois desse tratamento as mudas voltaram para as bancadas da estufa de produção de mudas. 
Aproximadamente 15 dias após a inoculação, surgiram sintomas típicos da mancha bacteriana nas folhas das mudas, que foi confirmada pelo teste da corrida bacteriana, que nada mais foi que verificar no microscópio, numa gota d'água sobre a lâmina, um corte do tecido foliar entre a área sadia e a área necrosada, um filete contínuo de células bacterianas saindo do tecido vegetal.

Foram inoculadas também, através de imersão, durante 4 horas, em uma suspensão bacteriana na concentração de $10^{6}-10^{7}$ ufc. $\mathrm{mL}^{-1}$ (Maringoni \& Kurosawa, 1994), 2\% das sementes de ambas as variedades que seriam utilizadas para realizar a semeadura do experimento em questão. Após a inoculação, as sementes foram retiradas da suspensão com auxílio de um coador e secas à sombra, durante 48 horas sob papel de filtro e à temperatura ambiente.

\subsubsection{Sistemas de irrigação}

Os sistemas de irrigação testados foram: nebulização, microaspersão e "floating", todos em ambiente protegido (estufa). No teste dos defensivos foi utilizado apenas o sistema de nebulização.

O sistema de nebulização e microaspersão já se encontravam montados e em pleno funcionamento. O sistema de nebulização foi programado para nebulizar de 5 em 5 minutos durante 30 segundos, 24 horas por dia. $O$ sistema de irrigação por aspersão encontrava-se na estufa de produção de mudas, e estava programado para irrigar 7 vezes ao dia, sendo que 2 vezes com duração de 2 minutos e 5 vezes com duração de 3 minutos, das 8:00 às 15:00 horas.

Somente para o sistema "floating" foi necessário a construção de canteiro de dimensão 4,0m $\times 1,5 \mathrm{~m}$ e altura o suficiente para que as bandejas de isopor flutuassem. A estrutura desse canteiro era de madeira bem resistente para suportar a pressão da água e o seu fundo foi aplainado com areia. Foi 


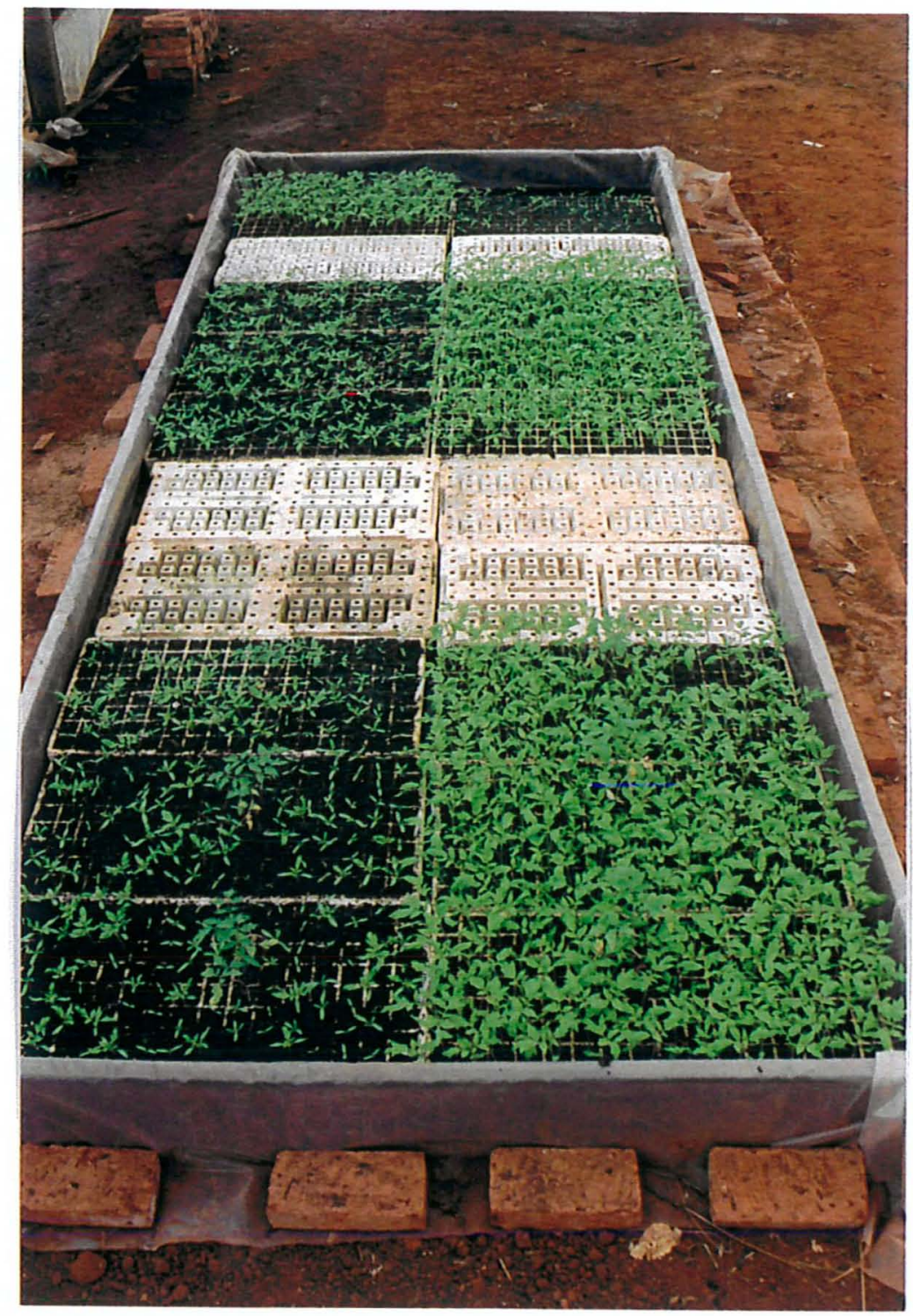

Figura 1 - Sistema de produção de mudas 'floating', instalado dentro da estufa de produção de mudas. 
utilizado plástico transparente de alta densidade na medida o suficiente para forrar todo o fundo e as laterais do 'floating'. Este sistema foi abastecido com água o suficiente para as bandejas flutuarem e sempre que houve necessidade. O 'floating' foi instalado dentro da estufa de produção de mudas, num local distante das bancadas que recebiam a irrigação por microaspersão.

\subsubsection{Avaliação da disseminação do patógeno}

Para avaliar a disseminação de Xanthomonas campestris pv. vesicatoria, cultivar tolerante e híbrido suscetivel foram semeadas em bandejas de isopor de 128 células preenchidas com substrato comercial Plantmax da Empresa Eucatex. Foi utilizado o mesmo substrato para cobrir as sementes após a semeadura.

As bandejas foram previamente sanitizadas através de imersão em solução a $2 \%$ de hipoclorito de sódio e, devidamente secas à sombra. Após a semeadura, foram mantidas em condições de cultivo protegido com irrigação correspondente ao seu tratamento.

\subsubsection{Tratamentos com sementes inoculadas}

Cada bandeja de 128 células recebeu 1 material tolerante ou suscetível ao patógeno. Cada material testado recebeu os seguintes tratamentos para o experimento com semente inoculada (preparada como descrito no item 3.3.2):
A) Testemunha, sem nenhuma semente inoculada com o patógeno, no sistema de irrigação por nebulização, aspersão e "floating";
B) Material tolerante com $2 \%$ das sementes inoculadas nos 3 sistemas de irrigação;
C) Material suscetivel com $2 \%$ das sementes inoculadas com o patógeno também nos 3 sistemas de irrigação.
O número de repetições foi 3 . 
Foram coletadas aleatoriamente 10 mudas de cada parcela, assim que estas atingiram porte ideal para transplante, com 4 a 5 folhas definitivas e 10 a $15 \mathrm{~cm}$ de altura, o que ocorreu aos 30 dias após a semeadura. Cada muda forneceu amostras de folhas, que devidamente imersas em água estéril deu origem a uma suspensão.

Cada suspensão foi plaqueada em meio de cultura semi-seletivo Tween (McGuire et al., 1986), onde foi utilizada uma alça de aro como medida padrão de suspensão por placa. A seguir, as placas de Petri foram colocadas na estufa à temperatura constante de $28^{\circ} \mathrm{C}$. Foi verificada a presença ou não da bactéria através da cristalização do meio de cultura.

Quando houve a cristalização, a colônia de aspecto similar ao do patógeno em estudo foi isolada em meio nutriente agar e, posteriormente, inoculada em mudas de tomate para testar a patogenicidade.

Para o preparo de $1 \mathrm{~L}$ do meio de Tween foram utilizados os seguintes ingredientes: $10 \mathrm{~g}$ de peptona; $10 \mathrm{~g}$ de brometo de potássio; $0,25 \mathrm{~g}$ de cloreto de potássio; $0,30 \mathrm{~g}$ de ácido bórico; $15 \mathrm{~g}$ de agar; $10 \mathrm{~mL}$ de tween $80 ; 50 \mathrm{mg}$ de cicloheximida; $65 \mathrm{mg}$ de cefalexina; $12 \mathrm{mg}$ de 5 -fluorouracil e $0,40 \mathrm{mg}$ de tobramicina.

Para o teste de patogenicidade, foram utilizadas mudas de 20 dias após a semeadura, do hibrido Hypeel 108, semeadas em bandejas de 128 células. Cada amostra da bactéria originou uma suspensão, que foi pulverizada na parte abaxial e adaxial das folhas das mudas até o ponto de escorrimento das gotas. Foi utilizado pulverizador manual.

As mudas eram retiradas cuidadosamente das bandejas e colocadas em um recipiente, apenas para serem inoculadas. Posteriormente, eram colocadas em bandejas limpas e sanitizadas, dispostas de forma a ficarem com 2 células de distância entre uma amostra e outra, além de serem devidamente identificadas. Foram utilizadas 4 mudas por amostra, que após o preenchimento da capacidade da bandeja, foram colocadas em câmara úmida. O procedimento posterior foi idêntico ao descrito no item 3.3.2. Os primeiros sintomas da 
mancha bacteriana, nas folhas das mudas, apareceram com 10 dias após a inoculação.

\subsubsection{Tratamentos com mudas inoculadas}

Foi utilizado $1 \%$ de mudas doentes, como descrito no item $3.3 .2 \mathrm{e}$ baseado no experimento realizado por Carmo (1995), onde foi constatado que utilizando esta porcentagem houve $100 \%$ de incidência da bactéria nas mudas de pimentão, em média 40 dias após a introdução de mudas doentes nas parcelas experimentais.

Para o experimento com muda inoculada:
A) Testemunha, sem nenhuma muda inoculada nos 3 sistemas de irrigação;
B) Material tolerante com $1 \%$ de muda inoculada nos 3 sistemas de irrigação;
C) Material suscetivel com $1 \%$ de muda inoculada nos 3 sistemas de irrigação.
O número de repetições foi 3 .

Para avaliar a incidência da bactéria neste tratamento procedeu-se da mesma forma que para o tratamento com sementes inoculadas.

\subsubsection{Tratamentos com defensivos}

Para o experimento dos defensivos:
A) Testemunha sem semente inoculada ou muda inoculada no sistema de nebulização;
B) Material tolerante com $1 \%$ de semente inoculada e $1 \%$ de muda inoculada no sistema de nebulização;
C) Material suscetível com $1 \%$ de semente inoculada e $1 \%$ de muda inoculada no sistema de nebulização.
O número de repetições foi 3 .

Para a avaliação do tratamento com defensivos, o procedimento foi semelhante aos anteriores, diferindo apenas pela aplicação em dose única dos defensivos nas mudas aos 15 dias após a semeadura, que foram mantidas apenas no sistema de nebulização. 
Foram aplicadas as concentrações recomendadas pelos fabricantes dos defensivos: $200 \mathrm{~g}$ do produto comercial à base de oxitetraciclina. $100 \mathrm{~L}^{-1}$ de água; $120 \mathrm{~g}$ do produto comercial à base de oxitetraciclina e sulfato de estreptomicina. $100 \mathrm{~L}^{-1}$ de água; $172 \mathrm{~g}$ do produto comercial à base de oxitetraciclina e cobre tribásico. $100 \mathrm{~L}^{-1}$ de água; $400 \mathrm{~g}$ do produto comercial à base de oxicloreto de cobre.100L $\mathrm{L}^{-1}$ de água juntamente com $300 \mathrm{~g}$ de mancozeb. $100 \mathrm{~L}^{-1}$ de água. Os produtos foram aplicados em pulverizadores manuais com capacidade de $0,5 \mathrm{~L}$, que possuiam apenas regulagem nos bicos pulverizadores (para jatos mais fortes ou jatos mais fracos) e as plantas foram pulverizadas até o ponto de escorrimento das gotículas da calda. Após a aplicação dos produtos esperou-se a devida secagem à sombra das gotículas da calda aplicada, para então recolocar as bandejas ao sistema de irrigação adotado.

\subsection{Critério de avaliação}

Para avaliar a ação do sistema de irrigação no híbrido suscetivel e na variedade tolerante, foi verificado nas mudas das bandejas, através de amostragem e devido preparo, a incidência da bactéria em meio de cultura semi-seletivo e posterior teste de patogenicidade em mudas de tomate.

A mesma avaliação foi realizada para verificar a ação dos defensivos nas mudas. Não foi possível fazer análise estatística em nenhum dos tratamentos, devido ao fato da incidência da doença ter sido muito baixa em algumas repetições. 


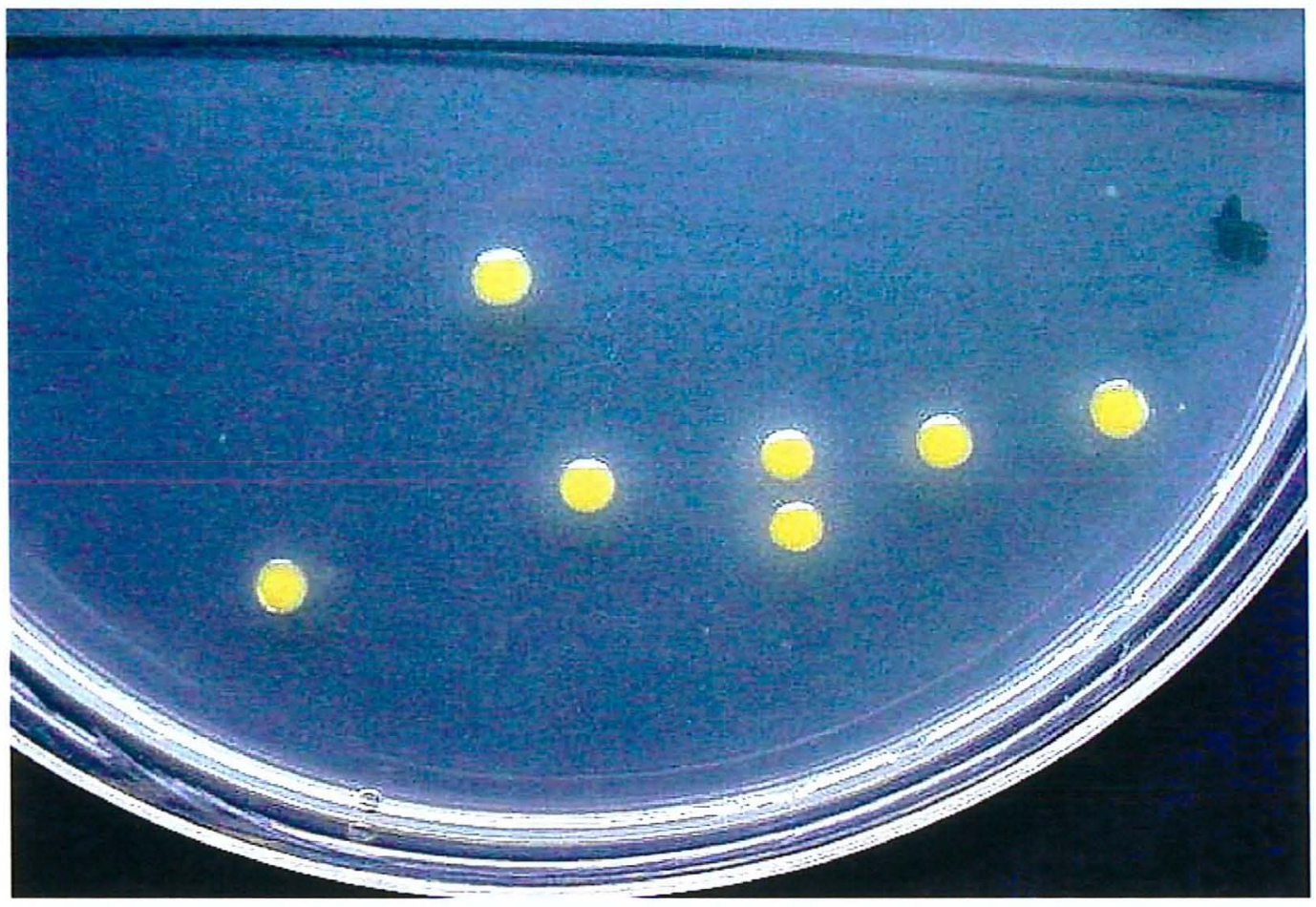

Figura 2 - Crescimento de colônias de Xanthomonas campestris pv. vesicatoria (Xcv) no meio semi-seletivo Tween, após 7 dias a $28^{\circ} \mathrm{C}$ obtidas de amostras de folhas de mudas de tomate, submetidas à muda inoculada como fonte de inóculo primário. As colônias de Xcv são distinguidas das demais pela presença de halos esbranquiçados ao seu redor, em conseqüência da lipólise de Tween. 


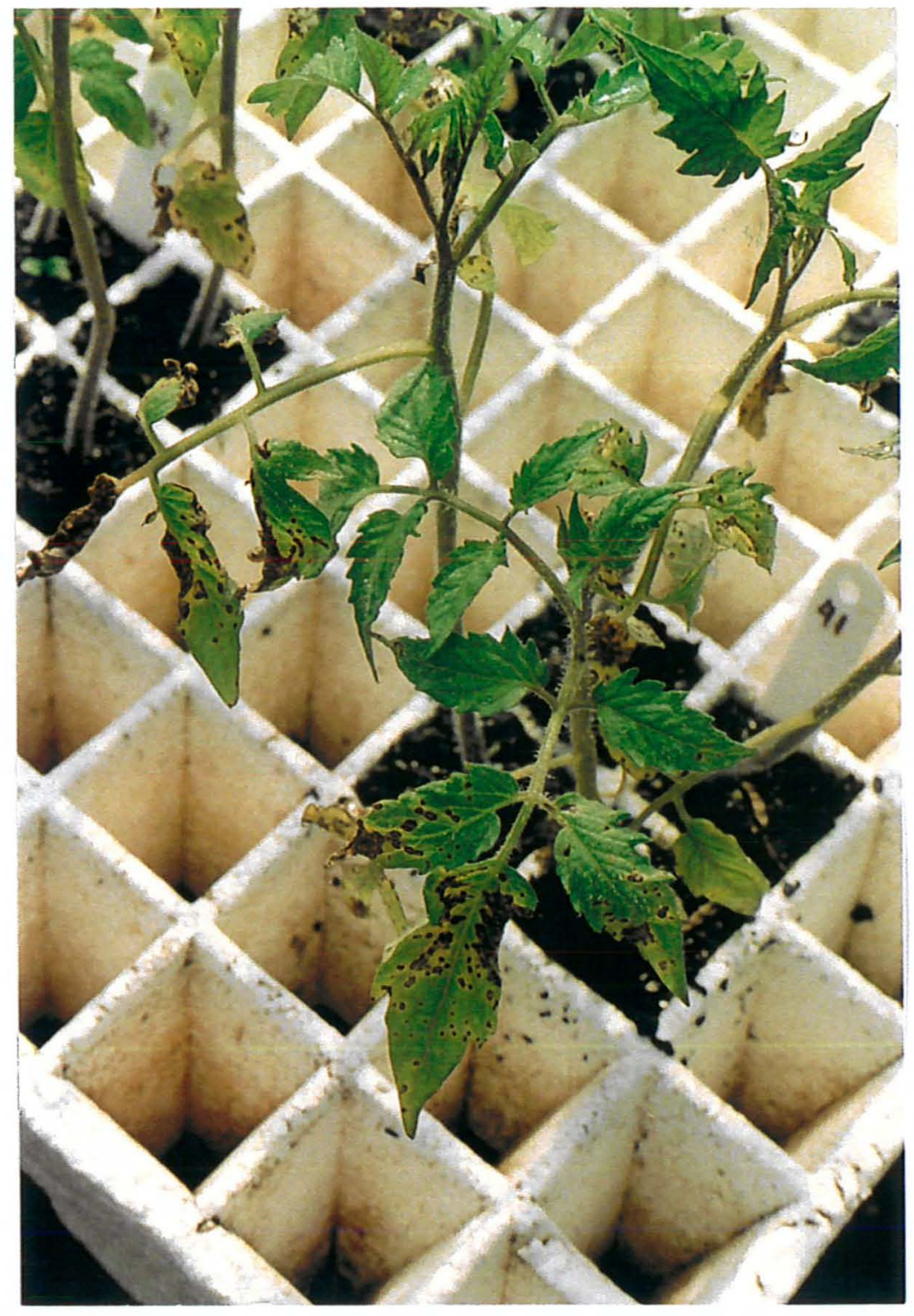

Figura 3 - Sintomas típicos da mancha bacteriana em mudas inoculadas, para o teste de patogenicidade, 10 dias após a inoculação. 


\section{RESULTADOS E DISCUSSÃO}

\subsection{Tratamento com sementes inoculadas}

As mudas do tratamento com sementes inoculadas foram amostradas, e logo a seguir, foram preparadas suspensões com as folhas das mudas e cada suspensão foi plaqueada no meio semi-seletivo Tween, onde foram obtidas as colônias com halo cristalizado 5 a 7 dias depois do plaqueamento, conforme a Tabela 2 e a Figura 4.

Os seguintes resultados foram obtidos: $10 \%$ de incidência de bactérias no sistema de irrigação por nebulização, na variedade Ohio 8245 , e $20 \%$, no híbrido Hypeel 108 (Figura 4). Houve também 3\% no sistema 'floating', na variedade Ohio 8245. No sistema por microaspersão não houve incidência de bactéria.

$\mathrm{O}$ isolamento das colônias em meio NA foi realizado, depois de devida identificação das colônias suspeitas de serem as da bactéria em estudo. Suspensões bacterianas foram preparadas e o teste de patogenicidade foi realizado em mudas de tomate com 20 dias após a semeadura, do híbrido Hypeel 108, semeadas em bandejas. O resultado obtido com as sementes inoculadas pode ser observado na Tabela 3.

Pelos resultados obtidos, pode-se afirmar que as colônias isoladas e inoculadas não eram de Xanthomonas campestris pv. vesicatoria. Este resultado demonstra que a semente, apesar de ser considerada a principal fonte de inóculo primário deste patógeno, nesta porcentagem e nestas condições, não foi capaz de disseminar a bactéria nem mesmo em condições 
de alta umidade, como foi o caso das mudas no sistema de irrigação por nebulização.

Neste sentido, Schuster \& Coyne (1974) afirmaram que o fato de um lote de sementes conter uma determinada bactéria, não significava, necessariamente, que essas sementes, quando plantadas originariam plantas doentes. Acrescentaram ainda que, o sucesso de bactérias associadas a sementes em infectarem plantas, após o plantio, era função da sua localização na semente, da estrutura anatômica e do tipo de germinação dessas sementes, assim como da capacidade de sobrevivência e das características da espécie bacteriana em si.

Saettler et al. (1989) observaram que a transmissão de bacterioses de plantas por sementes foi muito baixa, quase sempre menor que $1 \%$, o que significaria em termos práticos, que precisariam ser plantadas mais de 100 sementes para haver a possibilidade de uma planta infectada no campo.

Além dessas constatações, deve-se lembrar que além do fato de ter sido utilizado apenas $2 \%$ de sementes infectadas, houve também a interferência de fatores ambientais como a ocorrência de baixas temperaturas no período de produção de mudas, que mesmo estando em ambiente protegido, não havia controle da temperatura na estufa de produção de mudas, nem na estufa de nebulização. A temperatura máxima no mês de setembro foi de $27,5^{\circ} \mathrm{C}$ e a temperatura mínima de $13,6^{\circ} \mathrm{C}$, sendo a temperatura média de $20,6^{\circ} \mathrm{C}$.

Segundo Nayudu \& Walker (1960), a temperatura noturna de $16^{\circ} \mathrm{C}$ suprimiu a mancha bacteriana nas folhas de tomate, independente da temperatura diurna. Como a temperatura noturna chegou a ser menor que a citada pelo autor, provavelmente o que ocorreu neste experimento foi a supressão da bactéria devido à baixa temperatura, em todos os sistemas de irrigação, mesmo em condições de alta umidade relativa, como é o caso da estufa com o sistema de irrigação por nebulização. 
Tabela 2. Incidência de colônias bacterianas com halo cristalizado no tratamento com sementes inoculadas.

Sistemas irrigação ${ }^{1}$ Variedades $^{2}$ Repetições Incidência da cristalização

\begin{tabular}{llll}
1 & 1 & 1 & 0 \\
1 & 1 & 2 & 1 \\
1 & 1 & 3 & 2 \\
1 & 2 & 1 & 5 \\
1 & 2 & 2 & 0 \\
1 & 2 & 3 & 1 \\
2 & 1 & 1 & 0 \\
2 & 1 & 2 & 0 \\
2 & 1 & 3 & 0 \\
2 & 2 & 1 & 0 \\
2 & 2 & 2 & 0 \\
2 & 2 & 3 & 0 \\
3 & 1 & 1 & 0 \\
3 & 1 & 2 & 1 \\
3 & 1 & 3 & 0 \\
3 & 2 & 1 & 0 \\
3 & 2 & 2 & 0 \\
3 & 2 & 3 & 0 \\
\hline
\end{tabular}

${ }^{1}$ Sistemas de irrigação: 1=nebulização; 2=microaspersão e $3=$ 'floating'. ${ }^{2}$ Variedades: $1=$ Ohio 8245 e 2=Hypeel 108. 


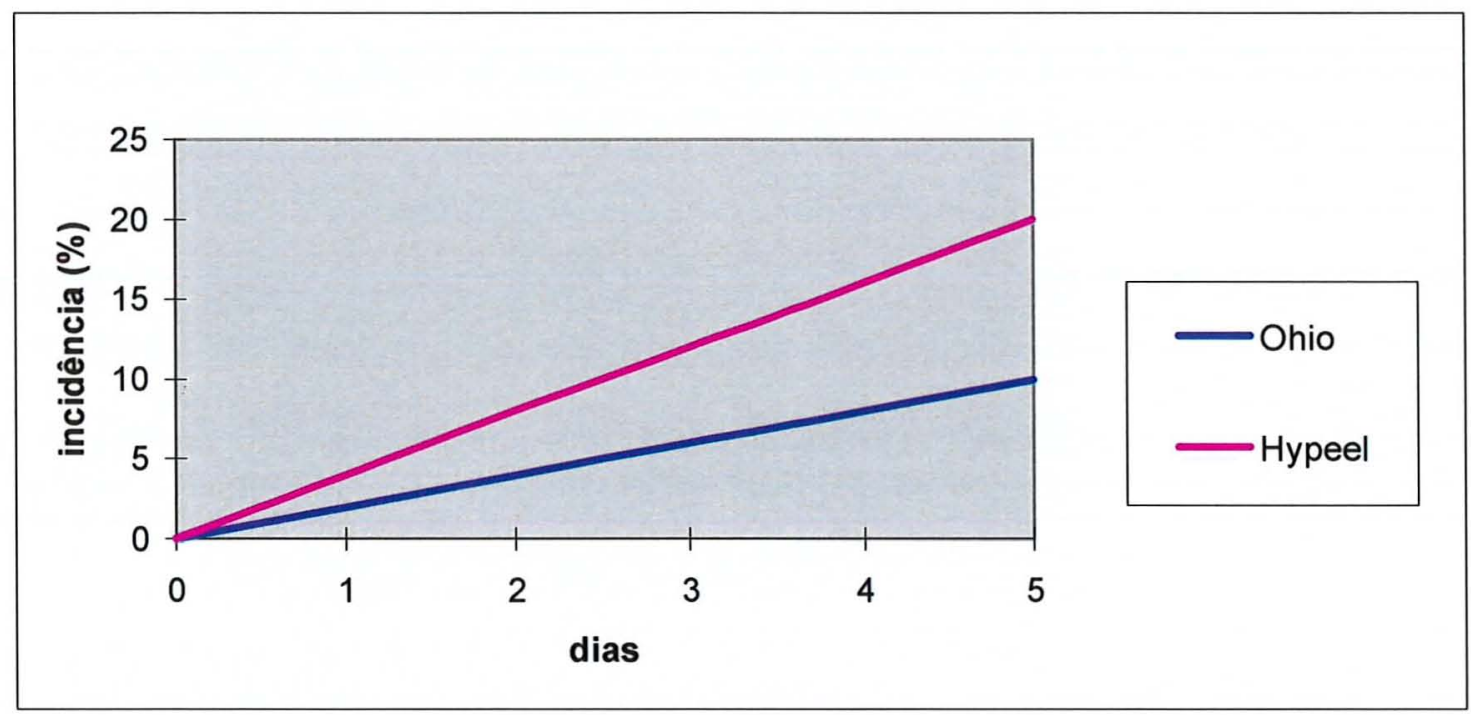

Figura 4 - Resultados de incidência de bactérias com halo cristalizado no meio semi-seletivo Tween, na cultivar Ohio 8245 e no híbrido Hypeel 108, no sistema de irrigação por nebulização. 
Tabela 3. Incidência de mancha bacteriana nas mudas inoculadas do tratamento de sementes inoculadas.

Sistemas irrigação ${ }^{1}$ Variedades $^{2}$ Repetições Incidência nas mudas

\begin{tabular}{llll}
\hline 1 & 1 & 1 & 0 \\
1 & 1 & 2 & 0 \\
1 & 1 & 3 & 0 \\
1 & 2 & 1 & 0 \\
1 & 2 & 2 & 0 \\
1 & 2 & 3 & 0 \\
2 & 1 & 1 & 0 \\
2 & 1 & 2 & 0 \\
2 & 1 & 3 & 0 \\
2 & 2 & 1 & 0 \\
2 & 2 & 2 & 0 \\
2 & 2 & 3 & 0 \\
3 & 1 & 1 & 0 \\
3 & 1 & 2 & 0 \\
3 & 1 & 3 & 0 \\
3 & 2 & 1 & 0 \\
3 & 2 & 2 & 0 \\
3 & 2 & 3 & 0 \\
\hline
\end{tabular}

'Sistemas de irrigação: 1=nebulização; 2=microaspersão e $3=$ 'floating'. ${ }^{2}$ Variedades: 1=Ohio 8245 e 2=Hypeel 108. 


\subsection{Tratamento com mudas inoculadas}

Foram adotados os mesmos procedimentos que no tratamento anterior, e os resultados podem ser observados nas Tabelas 4 e 5 e Figuras 4 e 5.

$\mathrm{Na}$ Tabela 4 e nas Figuras 4 e 5 , pode-se observar que a incidência de colônias com halo cristalizado foi de 13 e 43\%, no sistema por nebulização, nas variedades Ohio 8245 e híbrido Hypeel 108, respectivamente. 23 e 47\%, no sistema por microaspersão, e 0 e $27 \%$ no sistema 'floating'.

Após o teste de patogenicidade foram constatados $3 \%$ de Xanthomonas campestris pv. vesicatoria, no sistema de nebulização, na variedade Ohio 8245 .

O que se pode concluir é que mesmo utilizando como fonte de inóculo primário mudas inoculadas, apresentando sintomas foliares típicos da mancha bacteriana, a incidência do patógeno foi praticamente nula, ocorrendo apenas uma presença no sistema de irrigação por nebulização, na variedade Ohio 8245.

É muito provável que as baixas temperaturas ocorridas no periodo de crescimento das mudas (mínima de $13,6^{\circ} \mathrm{C}$ e máxima de $27,5^{\circ} \mathrm{C}$, sendo a média de $20,6^{\circ} \mathrm{C}$ ), suprimiu a bactéria, como foi observado por Nayudu \& Walker (1960). E também, a umidade do ambiente baixa (60,53\%) não favoreceu a disseminação das células bacterianas existentes na superfície das folhas lesionadas. Segundo Latin et al. (1995), a ocorrência de baixas umidades relativa após a irrigação resultou em níveis menores de doença, para irrigação por aspersão e por infiltração. Carmo (1995) também constatou incidências menores da doença, com clima frio e seco, estudando a disseminação da Xanthomonas campestris pv. vesicatoria em pimentão. 
Tabela 4. Incidência de colônias bacterianas com halo cristalizado no tratamento com mudas inoculadas.

Sistemas irrigação ${ }^{1}$ Variedades $^{2}$ Repetições Incidência da cristalização

1

1

1

1

1

1

2

2

2

2

2

2

3

3

3

3

3

3
1

1

1

2

2

2

1

1

1

2

2

2

1

1

1

2

2

2
1

2

3

1

2

3

1

2

3

1

2

3

1

2

3

1

2

3
0

3

1

5

4

4

0

0

7

8

2

4

0

0

0

4

2

2

'Sistemas de irrigação: 1=nebulização; 2=microaspersão e $3=$ 'floating'. ${ }^{2}$ Variedades: $1=$ Ohio 8245 e 2=Hypeel 108. 
Tabela 5. Incidência de mancha bacteriana nas mudas inoculadas no tratamento com mudas inoculadas.

Sistemas irrigação ${ }^{1}$ Variedades $^{2}$ Repetições Incidência nas mudas

$\begin{array}{llll}1 & 1 & 1 & 0 \\ 1 & 1 & 2 & 1 \\ 1 & 1 & 3 & 0 \\ 1 & 2 & 1 & 0 \\ 1 & 2 & 2 & 0 \\ 1 & 2 & 3 & 0 \\ 2 & 1 & 1 & 0 \\ 2 & 1 & 2 & 0 \\ 2 & 1 & 3 & 0 \\ 2 & 2 & 1 & 0 \\ 2 & 2 & 2 & 0 \\ 2 & 2 & 3 & 0 \\ 3 & 1 & 1 & 0 \\ 3 & 1 & 2 & 0 \\ 3 & 1 & 3 & 0 \\ 3 & 2 & 1 & 0 \\ 3 & 2 & 2 & 0 \\ 3 & 2 & 3 & 0\end{array}$

'Sistemas de irrigação: 1=nebulização; 2=microaspersão e 3= 'floating'. ${ }^{2}$ Variedades: $1=$ Ohio 8245 e 2=Hypeel 108. 


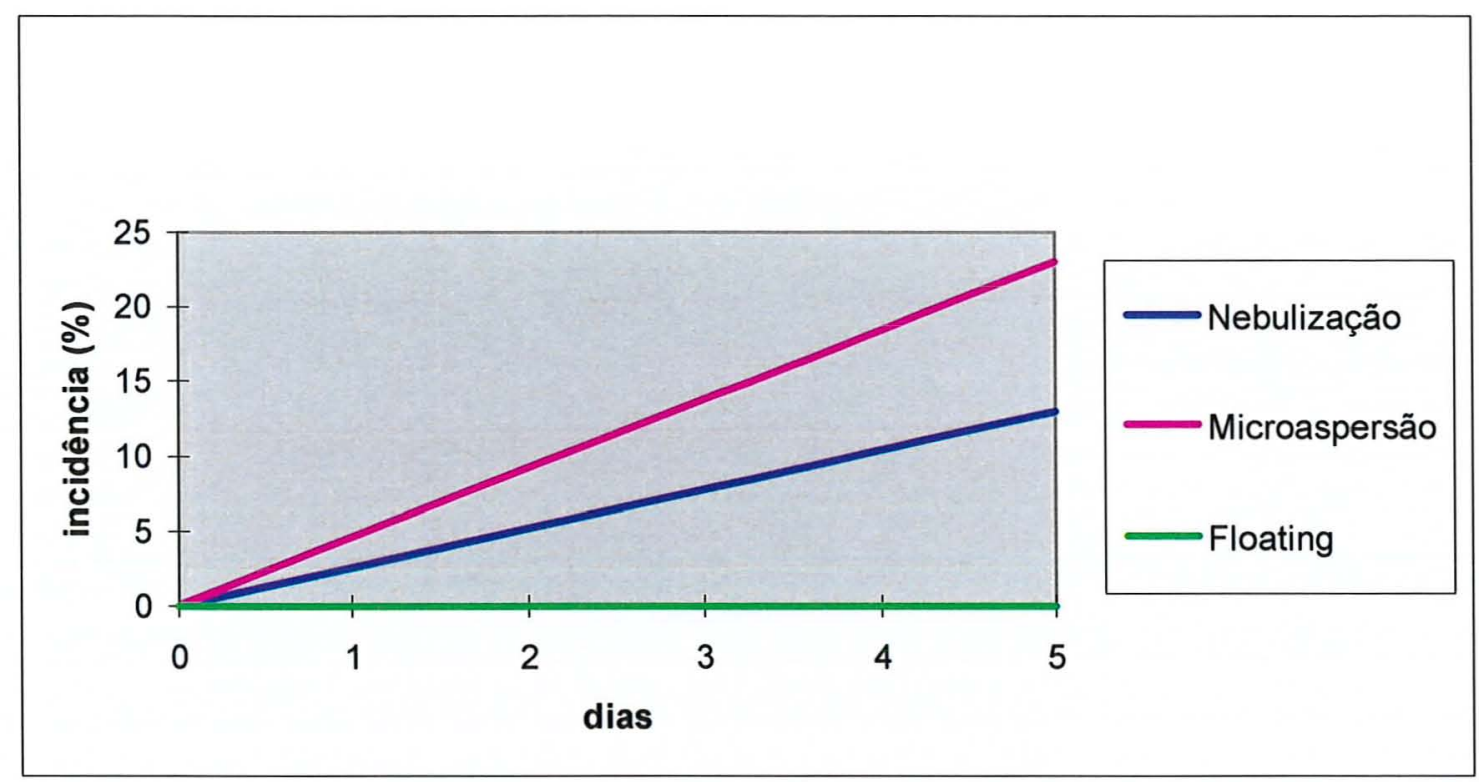

Figura 5 - Resultados de incidência de bactérias com halo cristalizado no meio semi-seletivo Tween na cultivar Ohio 8245.

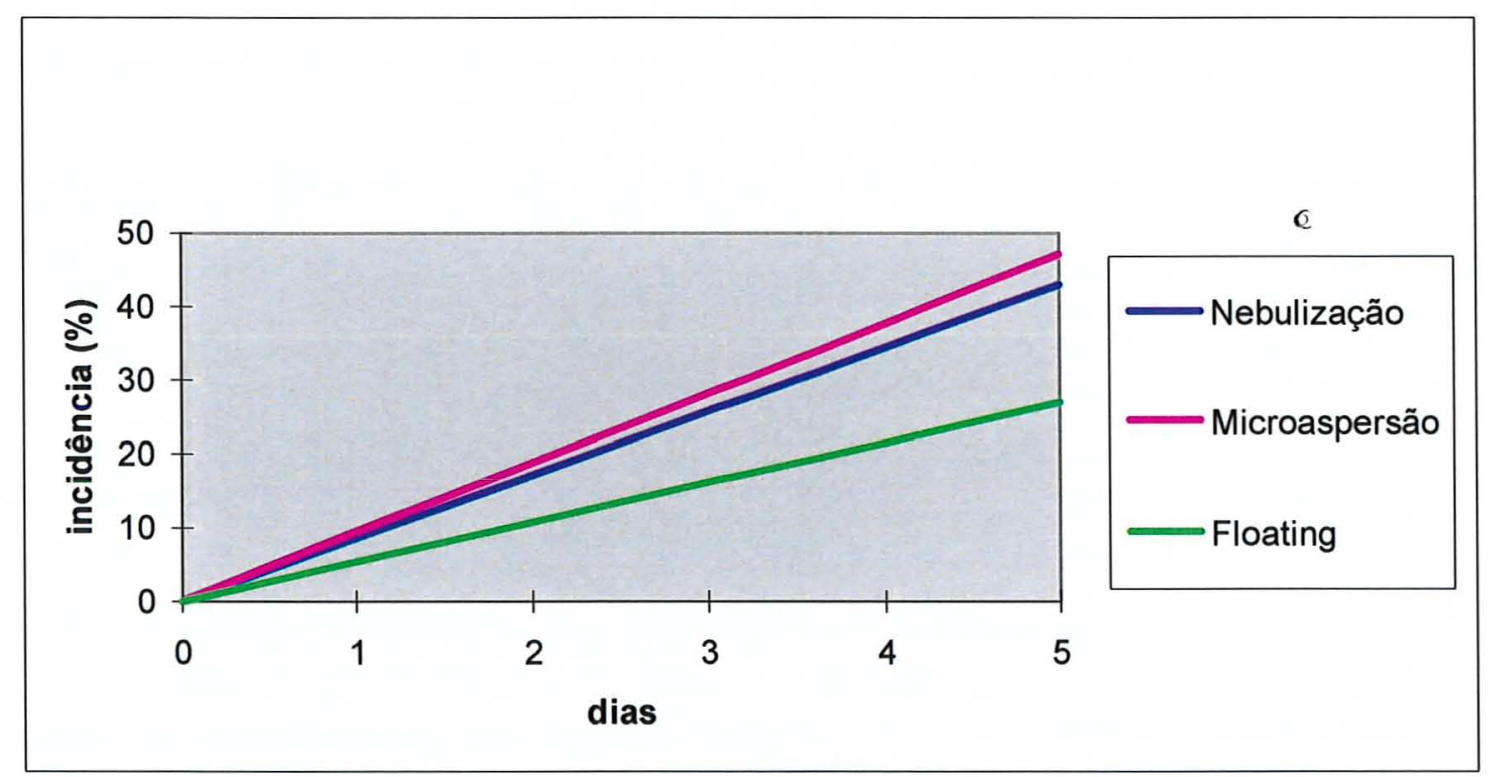

Figura 6 - Resultados de incidência de bactérias com halo cristalizado no meio semi-seletivo Tween no híbrido Hypeel 108. 


\subsection{Tratamento com defensivos}

Para obter os resultados com os defensivos, adotou-se os mesmos procedimentos que os tratamentos anteriores e, os resultados obtidos podem ser observados nas Tabelas 6 e 7 e nas Figuras 6 e 7 .

Tabela 6. Incidência de colônias bacterianas com halo cristalizado no tratamento com sementes e mudas inoculadas.

Defensivos $^{1}$

Repetições

Incidência da cristalização

1

1

1

2

2

2

3

3

3

4

4

4
1

2

3

1

2

3

1

2

3

1

2

3
5

6

7

2

0

0

1

1

2

6

2

0

${ }^{1}$ Defensivos: $1=0 x i t e t r a c i c l i n a+$ sulfato de estreptomicina; $2=0 x i t e t r a c i c l i n a+c o b r e$

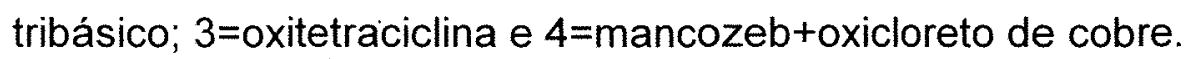

O oxitetraciclina associado com sulfato de estreptomicina apresentou $69 \%$ de incidência de bactérias com halo cristalizado, oxitetraciclina associado com cobre tribásico $7 \%$, oxitetraciclina $13 \%$ e mancozeb associado com oxicloreto de cobre $27 \%$ (Figura 6 ). 
No teste de patogenicidade, o oxitetraciclina associado com sulfato de estreptomicina não teve incidência da Xanthomonas campestris pv. vesicatoria, assim como o oxitetraciclina associado com cobre tribásico. Já o oxitetraciclina e mancozeb associado com oxicloreto de cobre apresentaram incidência da bactéria de 7 e $27 \%$, respectivamente, como mostra a Tabela 7 e a Figura 7.

Tabela 7. Incidência de Xanthomonas campestris pv. vesicatoria no tratamento de defensivos.

Defensivos $^{1}$

Repetições

Incidência do patógeno

1

1

1

2

2

2

3

3

3

4

4

4
1

2

3

1

2

3

1

2

3

1

2

3
0

0

0

0

0

0

0

0

2

6

2

0

${ }^{1}$ Defensivos: $1=0 x i t e t r a c i c l i n a+$ sulfato de estreptomicina; $2=0 x i t e t r a c i c l i n a+c o b r e$ tribásico; 3=oxitetraciclina e 4=mancozeb+oxicloreto de cobre. 
Com base nos resultados obtidos na incidência da bactéria no teste de patogenicidade, pode-se afirmar que tanto o oxitetraciclina associado com sulfato de estreptomicina, quanto o oxitetraciclina associado com cobre tribásico tiveram eficiência no controle de Xanthomonas campestris pv. vesicatoria, com as dosagens recomendadas pelos fabricantes. No entanto, o oxitetraciclina e o mancozeb associado com oxicloreto de cobre não tiveram a mesma eficiência que os produtos anteriores.

Estes resultados reforçam o que Maringoni et al. (1986) concluíram com relação a diversos antibióticos e fungicidas cúpricos, que também não apresentaram resultados satisfatórios no controle da mancha bacteriana.

O resultado obtido por Mclnnes et al. (1988) foi idêntico ao obtido neste experimento, no qual não houve controle do patógeno utilizando-se fungicida cúprico associado a mancozeb.

Apesar de Maringoni et al. (1986), Pohronezny et al. (1986) e Gitaitis et al. (1992) afirmarem que o uso contínuo da estreptomicina levou ao patógeno criar resistência a esse produto, foi o tratamento onde houve menor incidência de doença, e que, portanto, o produto aplicado mostrou-se eficiente, o que pode ter ocorrido pela 'estirpe' da bactéria estudada não apresentar resistência à estreptomicina. 


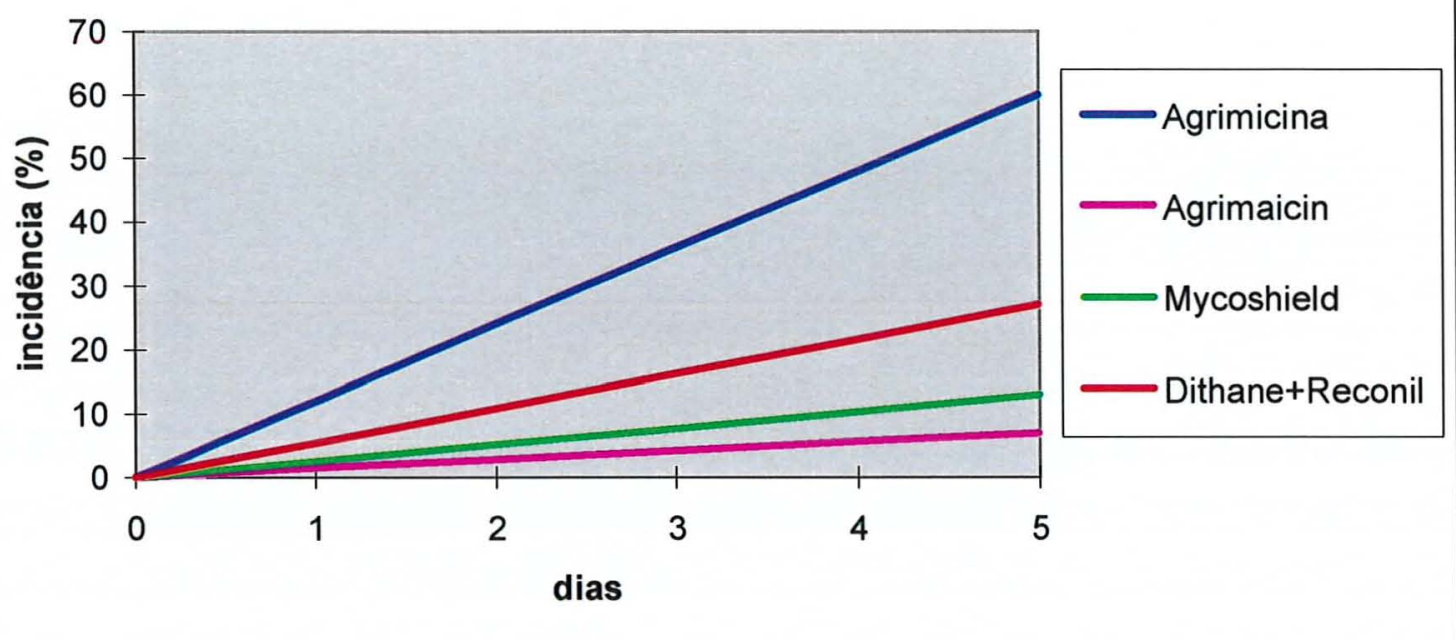

Figura 7 - Incidência de bactérias com halo cristalizado no meio semi-seletivo Tween.

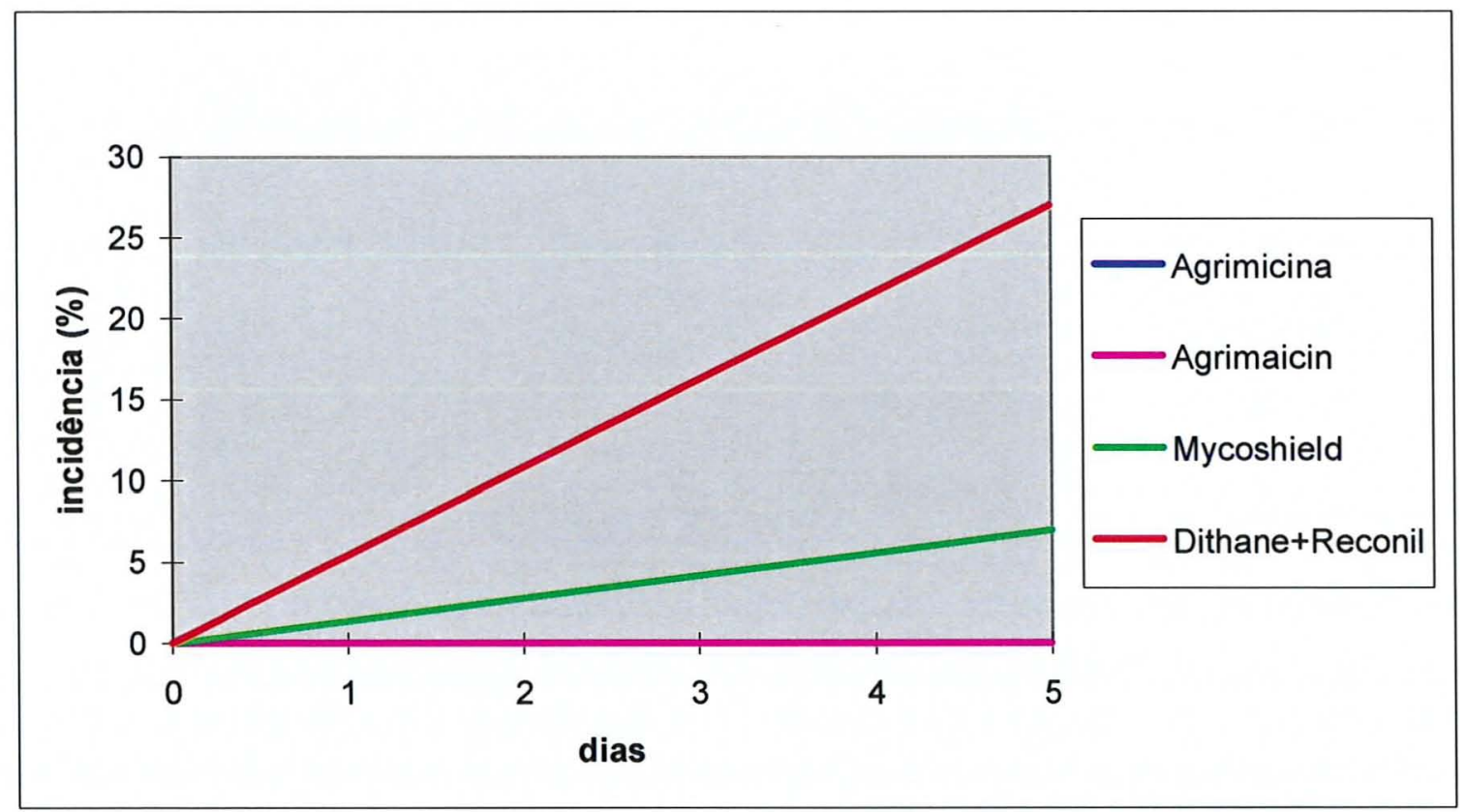

Figura 8 - Incidência de Xanthomonas campestris pv. vesicatoria no teste de patogenicidade. 


\section{CONCLUSÕES}

A porcentagem utilizada de sementes inoculadas $(2 \%)$ por parcela não se mostrou satisfatória, como fonte de inóculo primário de Xanthomonas campestris pv. vesicatoria, em mudas de tomate industrial.

As mudas inoculadas mostraram-se eficientes como fonte de inóculo primário.

As condições climáticas, como umidade relativa e temperatura, interferem de maneira incisiva no comportamento do patógeno sobre o hospedeiro.

Os defensivos, à base de oxitetraciclina associado a sulfato de estreptomicina e oxitetraciclina associado a cobre tribásico, devem ser considerados, como uma das formas de controle deste patógeno, e não como único método de controle.

Os fungicidas cúpricos associados ao mancozeb não são eficientes no controle da mancha bacteriana em mudas de tomate.

Há necessidade de maiores estudos para se determinar qual a quantidade de inóculo inicial, no caso de sementes de tomate, para que ocorra incidência de planta doente no campo. 


\section{REFERÊNCIAS BIBLIOGRÁFICAS}

ANDRIOLO, J.L.; BOEMO, M.P.; BONINI, J.V. Crescimento e desenvolvimento de mudas de tomateiro e melão empregando os métodos de irrigação por microaspersão, inundação subsuperficial e flutuação. Horticultura Brasileira, v.9, n.3, p.332-335, nov.2001.

BARROS, S.B.M. Avaliação de diferentes recipientes na produção de mudas de tomate (Lycopersicum esculentum Mill.) e pepino (Cucumis sativus L.). Piracicaba, 1997. 70p. Dissertação (Mestrado) - Escola Superior de Agricultura "Luiz de Queiroz", Universidade de São Paulo.

BEDENDO, I.P. Ambiente e doença. In: BERGAMIN FILHO, A.; KIMATI, H.; AMORIM, L. Manual de fitopatologia: princípios e conceitos. 3.ed. São Paulo: Agronômica Ceres, 1995. v.1, cap.18, p.331-341.

CARMELLO, Q.A.C. Nutrição e adubação de mudas hortícolas. In: GONÇALVES, A.L.; TESSARIOLI NETO, J.; PENTEADO, S.R.; SCARPARI FILHO, J.A.; SILVEIRA, R.B.A. Produção de mudas de alta qualidade em horticultura. São Paulo: Fundação Salim Farah Maluf, 1995. p.27-37.

CARMO, M.G.F. Epidemiologia da pústula bacteriana do pimentão, causada por Xanthomonas campestris pv. vesicatoria, em condições de viveiro. Viçosa, 1995. 88p. Tese (Doutorado) - Universidade Federal de Viçosa. 
CICCARONE, A.; DOWSON, W.J. Notas sobre algumas bactérias do tomateiro em São Paulo. O Biológico, v.25, n.7, p.131-133, 1959.

ESPINOZA, W. Manual de produção de tomate industrial no Vale do São Francisco. Brasilia: IICA, Escritório no Brasil, 1991. 301p.

FAO. Statistical database. http://www.fao.org. (13 dez. 2002).

FILGUEIRA, F.A.R. Manual de olericultura: cultura e comercialização de hortaliças. São Paulo: Ed. Agronômica Ceres, 1982.v.2, 357p.

FONTES, R.R. Efeitos de seis métodos de produção de mudas no crescimento inicial das plantas e na produção do tomateiro (Lycopersicum esculentum, Mill.). Viçosa, 1976. 44p. Dissertação (Mestrado) - Universidade Federal de Viçosa.

GARDNER, M.W.; KENDRICK, J.B. Bacterial spot of tomato. Journal of Agricultural Research, v.21, p.337-338, 1921.

GIORDANO, L.B.; SILVA, J.B.C.; BARBOSA, V. Escolha de cultivares e plantio. In: SILVA, J.B.C.; GIORDANO, L.B. Tomate para processamento industrial. Brasília: Embrapa Comunicação para Transferência de Tecnologia/Embrapa Hortaliças, 2000. p.36-60.

GITAITIS, R.; MACCARTER, S.; JONES, J. Disease control in tomato transplants produced in Georgia and Florida. Plant Disease, v.76, p.651656, 1992.

GOODE, M.J.; SASSER, M. Prevention - the key to controlling bacterial spot and bacterial speck of tomato. Plant Disease, v.64, p.831-834, 1980. 
HAAG, H.P.; HOMA, P. Absorção de nutrients pela cultura da berinjela. In: HAAG, H.P.; Minami, K. Nutrição mineral de hortaliças. Campinas: Fundação Cargill, 1981. p.433-446.

HAAG, H.P.; OLIVEIRA, G.D.; BARBOSA, V.; SILVA NETO, J.M. Marcha de absorção dos nutrientes pelo tomateiro (Lycopersicum esculentum Mill) destinado ao processamento industrial. In: HAAG, H.P.; MINAMI, K. Nutrição mineral de hortaliças. Campinas: Fundação Cargill, 1981. p.447474.

JONES, J.B.; POHRONEZNY, K.L.; STALL, R.E.; JONES, J.P. Survival of Xanthomonas campestris pv. Vesicatoria in Florida on tomato crop residue, weeds, seeds, and volunteer tomato plants. Phytopathology, v.76, p.430$434,1986$.

JONES, J.B.; STANLEY, C.D.; CSIZINSKY, A.A.; KOVACH, S.P.; McGUIRE, R.G. $\mathrm{K}$ and $\mathrm{N}$ fertilization rates influence susceptibility of trickle-irrigated tomato plants to bacterial spot. HortScience, v.23, n.6, p.1013-1015, 1988.

KRAMER, M. Mancha bacteriana do tomateiro. O Biológico, v.25, n.7, p.149, 1959.

KUROSAWA, C.; PAVAN, M.A. Doenças do tomateiro. In: KIMATI, H.; AMORIN, L.; BERGAMIN FILHO, A.; CAMARGO, L.E.A.; REZENDE, J.A.M. Manual de fitopatologia: doenças das plantas cultivadas. 3.ed. São Paulo: Agronômica Ceres, 1997. v.2, cap.64, p.690-719.

LATIN, R.; TIKHONOVA, I.; RANE, K. Factors affecting the survival and spread of Acidovorax avenae subsp. citrulli in watermelon transplant production facilities. Phytopathology, v.85, p.1413-1417, 1995. 
LIPTAY, A.; NICHOLLS, S. Nitrogen supply during greenhouse transplant production affects subsequent tomato root growth in the field. Journal of American Society of Horticultural Science, v.118, n.3, p.339-342, 1993.

LOBO, V.L.S. Herança e componente da resistência à mancha bacteriana em tomateiro. Brasília, 2000. 107p. Tese (Doutorado) - Universidade de Brasilia.

LOPES, C.A.; QUEZADO-SOARES, A.M. Doenças bacterianas das hortaliças: diagnose e controle. Brasília: EMBRAPA, CNPH, 1997. 70p.

MARINGONI, A.C.; KUROSAWA, C. Erradicação de Xanthomonas campestris pv. vesicatoria em sementes de tomateiro. Revista Brasileira de Sementes, v.16, n.2, p.191-194, 1994.

MARINGONI, A.C.; KUROSAWA, C.; BARBOSA, V.; SILVA NETO, J.M. Controle químico da mancha bacteriana (Xanthomonas campestris pv. vesicatoria (DOIDGE) Dye do tomateiro (Lycopersicon esculentum Mill.). Summa Phytopathologica, v.12, n.1, p.92-101, 1986.

McCARTER, S.M.; JONES, J.B.; GITAITIS, R.D.; SMITLEY, D.R. Survival of Pseudomonas syringae pv. tomato in association with tomato seed, soil, host tissue, and epiphytic weed hosts in Georgia. Phytopathology, v.73, p.1393-1398, 1983.

McGUIRE, R.G.; JONES, J.B.; SASSER, M. Tween media for semiselective isolation of Xanthomonas campestris pv. vesicatoria from soil and plant material. Plant Disease, v.70, p.887-891,1986. 
McGUIRE, R.G.; JONES, J.B.; STANLEY, C.D.; CSIZINSKY, A.A. Epiphytic populations of Xanthomonas campestris pv. vesicatoria and bacterial spot of tomato as influenced by nitrogen and potassium fertilization. Phytopathology, v.81, p.656-660, 1991.

MCINNES, T.B.; GITAITIS, R.D.; MCCARTER, S.M.; JAWORSKI, C.A.; PHATAK, S.C. Airborne dispersal of bacteria in tomato and pepper transplant fields. Plant Disease, v.72, p.575-579,1988.

MELTON, R.R.; DUFAULT, R.J. Nitrogen, phosphorus, and potassium fertility regimes affect tomato transplant growth. HortScience, v. 26, n.2, p.141$142,1991$.

MINAMI, K. Produção de mudas de alta qualidade em horticultura. São Paulo: T. A. Queiroz, 1995. 128p.

MINAMI, K.; PUCHALA, B. Produção de mudas de hortaliças de alta qualidade. Horticultura Brasileira, v.18, Supl.7, p.162-163, 2000.

MORTON, D.J. Bacterial spot development in excised pepper and tomato leaves at several temperatures. Phytopathology, v.56, p.1194-95, 1966.

NAKAMURA, K. Influência da temperatura na infecção de tomateiro por Xanthomonas campestris pv. vesicatoria. Summa Phytopathologica, v.16, p.106-110, 1990.

NASCIMENTO, W.S.; MORAES, M.H.D. Avaliação da qualidade de sementes de tomate para a indústria. Horticultura Brasileira, v.8, n.2, p.31, 1990. 
NAYUDU, M.V.; WALKER, J.C. Bacterial spot of tomato as influenced by temperature and age and nutrition of the host. Phytopathology, v.50, p.360-364, 1960.

OLIVEIRA, R.P.; SCIVITTARO, W.B.; VASCONCELOS, L.A.B.C. Avaliação de mudas de maracujazeiro em função do substrato e do tipo de bandeja. Scientia Agricola, v.50, n.2, p.261-266, 1993.

PEREIRA, P.R.G.; MARTINEZ, H.E.P. Produção de mudas para o cultivo de hortaliças em solo e hidroponia. Informe Agropecuário, v.20, n.200/201, p.24-31, set./dez. 1999.

PETERSON, G.H. Survival of Xanthomonas vesicatoria in soil and diseased tomato plants. Phytopathology, v.53, p.765-767, 1963.

PINTO, C.M.F.; CASALI, V.W.D. Origem e botânica do tomateiro. Informe Agropecuário, v.6, n.66, p.8-9, 1980.

POHRONEZNY, K.; MOSS, M.A.; DANKERS, W.; SCHENK, J. Dispersal and management of Xanthomonas campestris pv. vesicatoria during thinning of direct-seeded tomato. Plant Disease, v.74, p.800-805, 1990.

ROMEIRO, R.S. Bactérias fitopatogênicas. Viçosa: UFV, 2000. 283p.

ROTEM, J.; COHEN, Y. The relationship between mode of irrigation and severity of tomato foliage diseases in Israel. Plant Disease Reporter, v.50, p.635-639, 1966. 
SAETTLER, A.W.; SCHAAD, N.W.; ROTH, D.A. Detection of bacteria in seed and other planting material. Minneapolis: The American Phytopathological Society, 1989. 122p.

SCHUSTER, M.L.; COYNE, D.P. Survival mechanisms of prhytopathogenic bacteria. Annual Review of Phytopathology, v.12, p.199-221, 1974.

SILVA, J.B.C.; GIORDANO, L.B. Tomate para processamento industrial. Brasília: Embrapa Comunicação para Transferência de Tecnologia / Embrapa Hortaliças, 2000. 168p.

SONNENBERG, P.E. Olericultura especial. Cultura de: alface, alho, cebola, cenoura, batata e tomate. Goiânia: Universidade Federal de Goiás, Curso de Agronomia, 1985. pt.1, 188p.

SOUZA, R.J.; FERREIRA, A.A. Produção de mudas de hortaliças em bandejas: economia de sementes e defensivos. A Lavoura, v. 623, p.19-21, 1997.

TIMMER, L.W.; MAROIS, J.J.; ACHOR, D. Growth and survival of xanthomonads under conditions nonconductive to disease development. Phytopathology, v. 77, p.1341-1345, 1987.

TOMATO NEWS. www.tomatonews.com (13 dez. 2002).

VAKILI, N.G. Importance of wounds in bacterial spot (Xanthomonas vesicatoria) of tomatoes in the field. Phytopathology, v.57, p.1099-1103, 1967.

VOLCANI, Z. The effect of mode of irrigation and Wind direction on disease severity caused by Xanthomonas vesicatoria on tomato in Israel. Plant Disease Reporter, v. 53, p.459-461, 1969. 